UDK 902

ISSN 1330-0644

Vol. 38/1

ZAGREB, 2021.
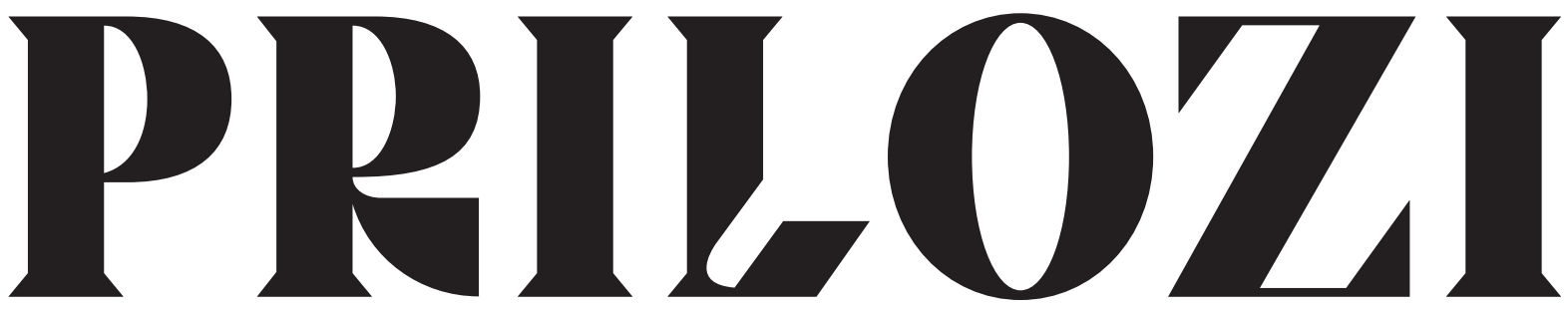

Instituta za arheologiju u Zagrebu 
Pril. Inst. arheol. Zagrebu, 38/1/2021

Str./Pages 1-104, Zagreb, 2021.
Izdavač/Publisher

INSTITUT ZA ARHEOLOGIJU

INSTITUTE OF ARCHAEOLOGY

Adresa uredništva/Address of the editor's office Institut za arheologiju/Institute of archaeology

HR-10000 Zagreb, Jurjevska ulica 15

Hrvatska/Croatia

Telefon/Phone ++385/(0)1 6150250

Fax $++385(0) 16055806$

e-mail: urednistvo.prilozi@iarh.hr

http://www.iarh.hr

Glavni i odgovorni urednik/Editor in chief

Marko DIZDAR

Tehnički urednici/ Technical editors

Marko DIZDAR

Katarina BOTIĆ

Uredništvo/Editorial board

Marko DIZDAR, Snježana VRDOLJAK, Viktória KISS (Budapest, HUN) (prapovijest/Prehistory), Goranka LIPOVAC VRKLJAN, Ivan RADMAN-LIVAJA (antika/ Antiquities), Tajana SEKELJ IVANČAN, Katarina Katja PREDOVNIK (Ljubljana, SLO), Natascha MEHLER (Wien, AUT), Juraj BELAJ, Tatjana TKALČEC (srednji vijek i novi vijek/Middle Ages and Modern era), Predrag NOVAKOVIĆ (Ljubljana, SLO) (metodologija/Methodology)

Izdavački savjet/Editorial advisory board

Dunja GLOGOVIĆ (Zagreb), Ivor KARAVANIĆ (Zagreb), Laszlo KÓVACS (Budapest, HUN), Kornelija MINICHREITER (Zagreb), Aleksandar RUTTKAY (Nitra, SK), Ivančica SCHRUNK (Minneapolis, USA), Željko TOMIČıĆ (Zagreb), Ante UGLEŠıĆ (Zadar)

Prijevod na engleski/English translation

Mario GAVRANOVIĆ, Zdravka HINCAK DARIS, Vinita RAMLJAK

Lektura/Language editor Ivana MAJER, Marko DIZDAR (hrvatski jezik/Croatian)

Marko MARAS (engleski jezik/English)

Korektura/Proofreads

Katarina BOTIĆ

Grafičko oblikovanje/Graphic design

Umjetnička organizacija OAZA

Računalni slog/Layout

Hrvoje JAMBREK

Tisak/Printed by

E-izdanja. Publikacija je dostupna u digitalnom obliku i otvorenom pristupu na

https://hrcak.srce.hr/prilozi-iaz

E-edition. The publication is available in digital and open access form at

https://hrcak.srce.hr/prilozi-iaz?lang=en

Ovaj rad licenciran je pod Creative Commons Attribution By 4.0 međunarodnom licencom /

This work is licenced under a Creative Commons Attribution By 4.0 International Licence

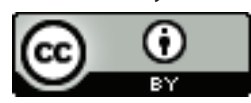

Naklada/lssued

400 primjeraka/400 copies

Prilozi Instituta za arheologiju u Zagrebu uključeni su u sljedeće indekse/

Prilozi Instituta za arheologiju u Zagrebu are included in following indices: des Deutschen Archaeologischen Instituts, Frankfurt a. Main Clarivate Analytics services - Web of Science Core Collection

CNRS/INIST - Centre National de la Recherche Scientifi que/L'Institut de I'Information Scientifi que et Technique, Vandoeuvre-lès-Nancy

EBSCO - Information servises, Ipswich

ERIH - European Reference Index for the Humanities, European Science Fundation, Strasbourg

SciVerse Scopus - Elsevier, Amsterdam
DYABOLA - Sachkatalog der Bibliothek - Römisch-Germanische Kommission 
Sadržaj

\section{Izvorni znanstveni radovi}

\author{
FILOMENA SIROVICA \\ MARTINA KORIĆ \\ SONJA KAČAR \\ SYLVIE PHILIBERT \\ ZLATKO PERHOČ \\ SANJIN MIHELIĆ
}

Vorganjska peć u kontekstu sjevernojadranskoga neolitika

MARIO GAVRANOVIĆ

SNJEŽANA ANTIĆ

CORNELIUS MEYER

IRENE PETSCHKO

JELENA BULATOVIĆ

LUKAS WALTENBERGER

A multi-phased burial mound in Novo Selo near

Bijeljina

\section{ZDRAVKA HINCAK DARIS}

KREŠIMIR FILIPEC

Histološka i makromorfološka metoda analize spaljenih kosti ljudi i životinja na primjeru rimskodobnih grobova sjeverozapadne nekropole Siscije (Sisak, Hrvatska)

\section{Contents}

\section{Original scientific papers}

\author{
FILOMENA SIROVICA \\ MARTINA KORIĆ \\ SONJA KAČAR \\ SYLVIE PHILIBERT \\ ZLATKO PERHOČ \\ SANJIN MIHELIĆ \\ Vorganjska peć cave site in the context of the \\ Northern Adriatic Neolithic \\ MARIO GAVRANOVIĆ \\ SNJEŽANA ANTIĆ \\ CORNELIUS MEYER \\ IRENE PETSCHKO \\ JELENA BULATOVIĆ \\ LUKAS WALTENBERGER \\ Višeslojni tumul u Novom Selu kod Bijeljine
}

\section{ZDRAVKA HINCAK DARIS \\ KREŠIMIR FILIPEC \\ Histological and Macromorphological Method of Burned Bones Analysis of Humans and Animals on the Example of Roman Period Graves of the Northwestern Necropolis of Siscia (Sisak, Croatia)}

GUIDELINES FOR CONTRIBUTORS 



\title{
Histološka i makromorfološka metoda analize spaljenih kosti ljudi i životinja na primjeru rimskodobnih grobova sjeverozapadne nekropole Siscije (Sisak, Hrvatska)
}

\section{Histological and Macromorphological Method of Burned Bones Analysis of Humans and Animals on the Example of Roman Period Graves of the Northwestern Necropolis of Siscia (Sisak, Croatia)}

Izvorni znanstveni rad

Antropologija

Original scientific paper

Anthropology

UDK/UDC 902:572](497.5 Sisak)"00/02"

Primljeno/Received: 12. 03. 2021.

Prihvaćeno/Accepted: 21. 06. 2021.

\author{
ZDRAVKA HINCAK DARIS \\ Odsjek za arheologiju \\ Filozofski fakultet Sveučilišta u Zagrebu \\ Ivana Lučića 8 \\ HR-10000 Zagreb \\ zhincak@ffzg.hr \\ Ured za forenzične znanosti Sveučilišta u Zagrebu \\ Trg Republike Hrvatske 14 \\ HR-10000 Zagreb \\ KREŠIMIR FILIPEC \\ Odsjek za arheologiju \\ Filozofski fakultet Sveučilišta u Zagrebu \\ Ivana Lučića 8 \\ HR-10000 Zagreb \\ kfilipec@ffzg.hr
}

\begin{abstract}
Prožimanje makromorfološke i histološke metode analize spaljenih kostiju iz arheološkoga konteksta pruža mogućnost boljega razumijevanja tafonomskih procesa koji mijenjaju osteološki materijal tijekom gorenja i nakon polaganja u zemlju. Također, omogućavaju bolje razumijevanje pogrebnih običaja. Analizirani su spaljeni ostaci ljudi i životinja iz dvadeset jednoga groba rimskodobne nekropole iz Siscije (Sisak, Hrvatska). Samo u dva groba spaljeni ostaci bili su očuvani u urnama, dok su ostali bili položeni u zemlju, u grobnu jamu. Očuvanost koštanih i dentalnih ostataka humanoga i animalnoga podrijetla je vrlo niska. Riječ je o fragmentima čija je duljina iznosila do $10 \mathrm{~mm}$, a masa uzoraka rijetko je prelazila $30 \mathrm{~g}$ po osobi. Histološka metoda analize omogućila je preciznije odjeljivanje humanih od animalnih fragmenata kosti $i$ odredbu doživljene starosti u rasponu od pet ili deset godina. Za slabo očuvane uzorke bilo je moguće utvrditi je li riječ o humanome materijalu te odrediti doživljenu starost u relacijama dijete - odrasla osoba. Rezultati analize potvrđuju važnost mikroskopske metode u ispitivanju doživljene starosti humanih i taksonomske pripadnosti životinjskih spaljenih ostataka.
\end{abstract}

Ključne riječi: antropološka analiza, histološka analiza, spaljene kosti, odredba doživljene starosti, rimskodobna nekropola, Siscia

The permeation of the macroscopic and histological method of analysis of burned bones from an archaeological context provides an opportunity to understand better the taphonomic processes which change osteological material during the burning process and after laying it in the ground. They also allow a better understanding of funeral customs. The burned remains of humans and animals from 21 graves of a Roman-age necropolis from Siscia (Sisak, Croatia) were analyzed. Only in two graves, the burned remains were preserved in urns, while the rest were laid in the ground, in a grave pit. The preservation level of bone and dental remains of human and animal origin is very low, these are fragments whose length was up to $10 \mathrm{~mm}$, and the weight of the samples rarely exceeded $30 \mathrm{~g}$ per person. The histological method of analysis enabled a more precise separation of human from animal bone fragments and the determination of age at death in the range of 5 or 10 years. For poorly preserved samples, it was possible to determine whether it was human material and to determine the age at death in the child-adult relationship. The analysis results confirm the importance of the microscopic method in examining the age of human and taxonomic affiliation of animal burned remains. 


\section{UVOD}

Sjeverozapadna nekropola je dio veće nekropole koja se prema grobnim jamama, u odnosu na navedeni iskop, pružala sigurno prema sjeverozapadu s jedne strane te u pravcu antičkoga grada Siscije na drugu stranu. Slični grobni ukopi, prije svega oni u obične jame bez grobne arhitekture, registrirani su na drugim sisačkim nekropolama (Wiewegh 2003). Oni su uobičajeni u Panoniji, Dalmaciji i na mnogim drugim područjima Rimskoga Carstva i ovako velika koncentracija na jednome mjestu govori u prilog jedne vjerojatno lokalne, autohtone zajednice (Gregl 1997). Stoga je moguće kako je riječ o stanovništvu sa sličnim obredom pokopa koji je stizao sa sjevernih područja rimske provincije Savije. U svakoj grobnoj jami nema očuvanih ljudskih kostiju, bilo zbog konfiguracije tla, bilo zbog kasnijih djelatnosti jer se obično nalaze blizu površine. To je vrlo važno kako kod identifikacije antičkih, tako i ranosrednjovjekovnih nekropola i grobalja u sjeverozapadnoj Hrvatskoj jer grobne jame bez urni su vrlo često identificirane kao obične jame. Ritual kakav je korišten kod pokopa stanovništva na sjeverozapadnim prilazima grada Siscije koristit će se diljem provincija, ponajviše kod autohtonoga stanovništva, a on će već tijekom 3. st. biti zamijenjivan novim ritualima, prije svega inhumacijom (Gregl 1997: 24; Wiewegh 2003: 33). Prema arheološkim predmetima nekropola se može datirati od 1. do 3. st.

Nalazi spaljenih kostiju ljudi i životinja, različitih stupnjeva očuvanosti, nisu rijetki na arheološkim nalazištima i mogu pružiti podatke o biološkom profilu jedinki, mogućim patološkim promjenama i traumama vidljivima na kostima te paleodemografiji određenih skupina te pogrebnim običajima. Za njihovo razumijevanje i razumijevanje kroz koje sve stadije kost prolazi tijekom gorenja potrebno je shvatiti na koji način gore tijela na lomačama. Eksperimentalno je potvrđeno da način i rezultat gorenja tijela u kućnome požaru nije jednak gorenju tijela na pogrebnoj lomači (De Haan 2015). Paljenje lomače, a nešto kasnije i tijela, započinje s nekoliko plamenova manjega opsega koji su laminarne strukture. lako plamen takve strukture ima ograničeno djelovanje, može dosezati vrlo visoke temperature. Razgorena lomača s otvorenim pristupom zraka gori turbulentnim plamenom koji u najjačoj fazi dostiže temperaturu od $800-1100{ }^{\circ} \mathrm{C}$, dok primjerice masne naslage tijela započinju gorjeti već na $250{ }^{\circ} \mathrm{C}$. Promjene kroz koje kost prolazi gorenjem opisao je Thompson jasno definirajući četiri faze: dehidraciju $\left(100-600{ }^{\circ} \mathrm{C}\right)$, raspadanje $\left(300-800^{\circ} \mathrm{C}\right)$, inverziju $\left(500-1100^{\circ} \mathrm{C}\right)$ i fuziju (iznad 700 ${ }^{\circ} \mathrm{C}$ ) (Thompson 2004). Uobičajeno je da koštani ostaci tijela koja su potpuno spaljena na lomači pokazuju ujednačenu boju. Grafikon s fazama promjene boje površine kosti $s$ porastom temperature odjeljuje promjene boje kosti koje gore na zraku od onih zaštićenih u gornjem sloju tla (Walker et al. 2008). Ipak, prema nijansama spaljenih kostiju može se odrediti u kakvom je položaju tijelo položeno na lomaču: na leđa, trbuh ili bočno. Naime, dijagrami pokazuju određene regije tijela i odnose različitih brzina i uzoraka gorenja (Symes et al. 2015). Također, rezultati kremacije neće biti isti za sve osteološke elemente uko-

\section{INTRODUCTION}

Northwestern necropolis is part of a larger necropolis which according to the grave pits, from said excavation, stretched certainly to the northwest on the one hand and in the direction of the ancient city Siscia on the other side. Similar burials, primarily those in ordinary pits without grave architecture, have been registered in other Sisak necropolises (Wiewegh 2003). They are common in Pannonia, Dalmatia and many other areas of the Roman Empire. Such a large concentration in one place speaks in favor of a probably local, indigenous community (Gregl 1997). It is, therefore, possible that it was an indigenous population with a similar funeral rite coming from the northern areas of the Roman province Pannonia Savia. There are no preserved human bones in each grave pit, either due to soil configuration or later activities, as they are usually located close to the surface. This is very important in the identification of both Roman and early medieval necropolises and cemeteries in northwestern Croatia because grave pits without urns are often identified as ordinary pits. The ritual used in the burial of the population on the northwestern approaches to the city of Siscia will be used throughout the provinces, especially among the indigenous population, and it will be replaced by new traditions during the $3^{\text {rd }}$ century, primarily by inhumation (Gregl 1997: 24; Wiewegh 2003: 33). According to archaeological finds, the necropolis can be dated from the $1^{\text {st }}$ to the $3^{\text {rd }}$ century.

Finds of burned bones of humans and animals, in varying degrees of preservation, aren't uncommon at archaeological sites and provide a large amount of information on the biological profile of individuals, possible pathological changes and trauma visible on bones and paleodemography of certain groups, and funeral customs. To understand cremation is necessary to understand how the body burns on a pyre. It has been experimentally confirmed that the manner and result of burning a body in a house fire is not the same as burning a body on a funerary pyre (De Haan 2015). The ignition of the pyre, and a little later the body, begins with several smaller-scale flames that are laminar structures. Although the flame of such a structure has limited action, it can reach very high temperatures. A burning pyre with open-air access burns with a turbulent flame, which in the strongest phase reaches a temperature of $800-1100^{\circ} \mathrm{C}$, while, for example, body fat begins to burn already at $250^{\circ} \mathrm{C}$. Thompson describes the changes that the bone undergoes by burning, clearly defining 4 phases: dehydration $\left(100-600^{\circ} \mathrm{C}\right)$, decomposition $\left(300-800^{\circ} \mathrm{C}\right)$, inversion $\left(500-1100^{\circ} \mathrm{C}\right.$ ) and fusion (above $700^{\circ} \mathrm{C}$ ) (Thompson 2004). It is usual for bone remains of the body completely burned on the pyre to show a uniform colour. The graph with the phases of the colour change of the bone surface with temperature increasing separates the colour change of bone burning in the air from those protected in the upper soil layer (Walker et al. 2008). However, according to the burned bones' shades, it can be determined in what position the body is placed on the pyre: on the back, front or sideways. The diagrams show specific regions of the body and the relationships of different burning rates and patterns (Symes et al. 2015). Also, the results of cremation will not be the same for all osteological elements if 
liko se lomača nalazi na ravnome položaju ili je ukošena, primjerice na padini. Eksperimenti su pokazali kako je od završetka procesa kremiranja do skupljanja koštanih i zubnih ostataka prolazi u prosjeku deset sati, iako će stvarno vrijeme ovisiti o vremenu i godišnjim dobima tijekom kojih se kremiranje vrši (Hincak et al. 2007). Osnovu antropološke metode istraživanja spaljenoga materijala predstavlja makroskopska analiza, dok u većini slučajeva histološka metoda samo upotpunjava već ranije dobivene rezultate. Problem nastaje u slučaju vrlo fragmentiranoga i slabo očuvanoga spaljenog koštanog materijala čiji uzorci rijetko prelaze dužinu od 10 do $20 \mathrm{~mm}$, poput osteološkoga materijala iz sjeverozapadne nekropole Siscije u središnjoj Hrvatskoj obrađenoga u ovome radu. Histološka metoda identifikacije prošla je dugi put od jednostavnoga odijeljivanja ljudskih od životinjskih ostataka prije više od stotinu godina (Kenyeres, Hegyi 1903). Već je tada uočen poseban problem pri odredbi, patološke promjene na kostima koje su dobro vidljive na preparatima, poput raznih upalnih stanja kosti ili rahitisa. Početak razvijanja histoloških metoda obuhvatio je preciznu analizu životinjskih kostiju prema izbruscima čvrstoga sloja dijafiza dugih kosti, a kasnije su utvrđene veličine promjera osteona za pojedine životinjske vrste (Lochte 1914; Walcher 1950; Ponsold 1967; Eidlin 1974; Hillier, Bell 2007). Upravo razlikovanje koštane histomorfometrije različitih vrsta sisavaca omogućilo je taksonomsku klasifikaciju životinjskih ostataka (Barnes et al. 2000; Dittmann et al. 2006).

Histološke analize humanoga koštanog materijala ubrzo su pokazale širu mogućnost, odredbu doživljene starosti odraslih osoba, iako u širem rasponu. Metode za takvu odredbu zasnivaju se na stupnju pregradnje osteona, njihovome broju i izgledu u uzorku čvrstoga sloja kosti (substantia compacta) odraslih osoba (Stout, Paine 1992; Streeter 2012). Do danas, istraživanja su obuhvatila različite anatomske elemente, no za ovo istraživanje najzanimljivija su ona na dijafizama dugih kostiju (Kerley 1965; Kerley, Ubelaker 1978; Pfeiffer 1980; Stout, Gehlert 1982; Frost 1987; Stout, Stanley 1991; Ericksen, Stix 1991; Lynnerup et al. 2006; Robling, Stout 2008; Han et al. 2009; Villa, Lynnerup 2010).

Analiza spaljenih fragmenata kostiju, osim histološke analize, podrazumijeva i razumijevanje procesa termalne razgradnje minerala u kostima (Ubelaker 2009; Symes et al. 2015; Thompson et al. 2016). Taj proces je povezan s organskim sadržajem u kostima i može se razlikovati, ovisno o koštanome elementu. Gorenje i visoka temperatura uzrokuju promjenu boje, oblika, dužine i djelomice širine kosti te često dovode do njezine fragmentacije. Provedeni su brojni eksperimenti koji su obuhvatili makromorfološke, ali i mikroskopske promjene na spaljenim fragmentima kostiju uslijed različitoga intenziteta topline, različitoga trajanja gorenja i izgaranja kao i promjena u strukturi kostiju (Gonçalves et al. 2011; Thompson et al. 2013; Snoeck et al. 2016). Histološku metodu moguće je upotrijebiti samo za uzorke kostiju kod kojih je, bez obzira na visoku temperaturu, ostala očuvana histološka građa kostiju. the pyre is in a flat position or is sloping, for example, on a slope. Experiments have shown that it takes an average of ten hours to complete the cremation process to the collection of bone and tooth debris, although the exact time will depend on the time and seasons during which the cremation is performed (Hincak et al. 2007). The anthropological method of the research of burned material is macroscopic analysis, while in most cases, the histological method only complements the previously obtained results. The problem arises in very fragmented and poorly preserved burned bone material, whose samples rarely exceed 10 to $20 \mathrm{~mm}$ in length, such as the osteological material from the northwestern necropolis of Siscia in central Croatia, treated in this paper. The histological method of identification has come a long way since the simple separation of human from animal remains more than a hundred years ago (Kenyeres, Hegyi 1903). Even then, a special problem with the determination was noticed, pathological changes in the bones that are well visible on the preparations, such as various inflammatory bone conditions or rickets. The beginning of the development of histological methods included precise analysis of animal bones, according to shards of the solid layer of cortical substance of diaphysis of the long bones, and later the values of osteon diameters from individual animal species were determined (Lochte 1914; Walcher 1950; Ponsold 1967; Eidlin 1974; Hillier, Bell 2007). Differentiation of bone histomorphometry of different mammalian species allowed taxonomic classification of animal remains (Barnes et al. 2000; Dittmann et al. 2006).

Histological analyses of human bone material soon showed a broader possibility, determining adult life expectancy, although in a broader range. Methods for such a provision are based on the degree of osteon remodeling, their number, and appearance in a sample of the compact substance of bone (substantia compacta) of adults (Stout, Paine 1992; Streeter 2012). To date, research has included various anatomical elements, but the most interesting for this research are those on long bone diaphyses (Kerley 1965; Kerley, Ubelaker 1978; Pfeiffer 1980; Stout, Gehlert 1982; Frost 1987; Stout, Stanley 1991; Ericksen, Stix 1991; Lynnerup et al. 2006; Robling, Stout 2008; Han et al. 2009; Villa, Lynnerup 2010).

The analysis of burned bone fragments, in addition to histological analysis, involves understanding the process of thermal decomposition of minerals in bones (Ubelaker 2009; Symes et al. 2015; Thompson et al. 2016). This process is related to bones organic content and can vary, depending on the bone element. Burning and high temperature cause a change in the colour, shape, length and partly the width of the bone and often lead to its fragmentation. Numerous experiments were performed, which included macromorphological and microscopic changes on burned bone fragments, which occur due to different heat intensity, different duration of burning and combustion, as well as changes in bone structure (Gonçalves et al. 2011; Thompson et al. 2013; Snoeck et al. 2016). The histological method can only be used for bone samples in which, despite the very high temperature, the histological structure of the bones has been preserved. 


\section{MATERIJAL I METODE}

Sjeverozapadna nekropola Siscije otkrivena je slučajno pregledom terena komunalne zone od Ulice Vlade Janjića Cape na istoku protežući se prema zapadu, južno od Zagrebačke ulice u Sisku. Na cijelom potezu uočeni su sitni ulomci rimskih keramičkih posuda izbačenih kod različitih prekopavanja terena. Zaštitna arheološka istraživanja na mjestu izgradnje Stanice za tehnički pregled vozila Sisak (Zagrebačka bb) započela su 25. travnja, a svi su radovi završeni do 15. svibnja 2003. pod vodstvom dr. sc. Krešimira Filipca iz Arheološkoga zavoda Filozofskoga fakulteta Sveučilišta u Zagrebu. Istaženi su dijelovi rimske sjeverozapadne nekropole Siscije, a sveukupno je zabilježeno 45 grobova. Na istraženoj površini veliki broj grobova bio je jako oštećen radom građevinskih strojeva, tako da se za veliki broj mogla registrirati samo pozicija groba. Prema izbačenoj građi nađenoj u iskopu zemlje pored sonde broj uništenih je jednak ili veći od onih koji je registriran na istraženoj površini. Analiza pokretnoga arheološkog materijala s lokaliteta sjeverozapadna nekropola Siscije nije objavljena.

Najveći broj registriranih grobova bio je ukop u običnu jamu nepravilnoga oblika, u dva slučaja registrirana je grobna jama s urnom u vidu obične glinene posude položene u jamu (grobovi 1 i 2), u jednome slučaja zabilježena je grobna jama sa zapečenim bočnim stranama (grob 30), a u jednom slučaju grobna jama s konstrukcijom u vidu posloženih kamena i opeka (grob 44), dok u dva slučaja (grobovi 31 i 45) imaju oblik grobne rake zaobljenih stranica u koje je zasuta veća količina gara i pepela. Stranice grobnih raka kod većine grobova nisu bile zapečene, što možda govori u prilog tomu da lomača nije bila podignuta iznad groba. U najvećem broju bilo je riječ o običnim grobnim jamama nepravilnih oblika u koji je zasut sadržaj s lomače. Veliki dio grobova registriran je u najdonjem dijelu, bez cjelovitoga ili uopće bez sadržaja. O tome je li bilo slučajeva simboličnoga ukopa ne može se govoriti zbog općenito slabe očuvanosti grobnih jama. U gotovo svim jamama nađeni su gar i pepeo, a samo u nekima sitne čestice ljudskih kostiju. $U$ ponekim je registriran samo čavao, željezni predmet, manja ili veća količina najrazličitija ulomaka rimskih keramičkih posuda, tanjura, većih i manjih lonaca različitih veličina, zdjela, manjih i većih vrčeva, amfora, tarionik, kadionica, pršljen, stakleni lakrimariji, ulomci staklenih posuda, svjetiljki te različiti metalni i brončani predmeti, čavli, fibula i brončani novac. Brončani novac pripada caru Probu (276.-282. g.). Općenito o dataciji ponajviše svjedoče različiti oblici keramičkih i staklenih posuda te fibule koji se datiraju u 2. i 3. st. Na deponiju su nađene dislocirane građevinskim strojevima kompaktne grobne cjeline, tj. uništeni odnosno preneseni grobovi A, B i C. Cjelovito je istražen otkriveni prostor nekadašnje veće rimske nekropole, odnosno ono što je od nje ostalo. Tako se prema grobu 37 uz istočni rub groblja jasno vidjelo da je prosječna dubina dna grobova bila 10 do $15 \mathrm{~cm}$ viša od dna na koju je sonda bila snižena. Može se reći kako je bilo više grobova na toj poziciji te da je veći dio sasvim uništen,

\section{MATERIAL AND METHODS}

The northwestern necropolis of Siscia was discovered by the archaeological field survey in the part of the communal zone from Vlade Janjića Cape Street in the east stretching to the west, south of Zagrebačka Street in Sisak. On the whole stretch, small fragments of Roman ceramic vessels thrown out during various excavations of the terrain were noticed. Rescue archaeological excavation at the Technical Inspection Station's construction site (Zagrebačka bb) began on $25^{\text {th }}$ April. All works were completed until 15 $15^{\text {th }}$ May 2003 led by PhD. Krešimir Filipec from the Archaeological Institute of the Faculty of Humanities and Social Sciences, University of Zagreb. Parts of the Roman northwestern necropolis of Siscia were explored, and a total of 45 graves were registered. On the investigated area, a large number of graves were severely damaged by the operation of construction machinery, so that for a large number only the position of the grave could be registered. According to the ejected material found in the discarded earth next to the probe, the number of destroyed graves is equal to, or greater than those registered on the investigated area. An analysis of movable archaeological material from the north western necropolis of Siscia has not been published.

The most significant number of registered graves refers to burial in an ordinary pit of irregular shape. In two cases, a grave pit with an urn in the form of an ordinary clay vessel placed in the pit was registered (graves 1 and 2). Also, in one case, a grave pit with burned sides was recorded (grave 30), and in one case a grave pit with a structure in the form of stacked stones and bricks (grave 44), while in two cases (graves 31 and 45) a grave pit has rounded sides with a large amount of soot and ash. In most graves, the sides of a pits were not scorched, which may suggest that the pyre was not raised above the grave pit. Most of them were ordinary grave pits, irregular in shape, in which the contents of the pyre were filled. A large part of the graves is registered in the lowest part, without complete contents. Whether there were any cases of symbolic burial cannot be said due to the generally poor preservation of grave pits. In almost all pits soot and ashes were found, and only some pits contained tiny particles of human bones. In some cases, only nail, iron object, small or large quantities of various fragments of Roman ceramic vessels, plates, larger and smaller pots of various sizes, bowls, small and large jugs, amphorae, mortar, censer, whorl, glass lacrimarium, fragments of glass vessels, lamps and various metal and bronze objects, nails, fibula and bronze coins were registered. The burned bronze coin belongs to Emperor Probus (276-282). In general, the dating is most evidenced by various forms of ceramic and glass vessels together with fibulae dated to the $2^{\text {nd }}$ and $3^{\text {rd }}$ century. Compact grave units dislocated by construction machines were found at the landfill, i.e. graves A, B and C were destroyed or transferred. The discovered area of the former larger Roman necropolis, i.e. what is left of it, has been thoroughly explored. In this way, according to the grave 37, along the eastern edge of the cemetery, it was clear that the average depth of the bottom of the graves was 10 to $15 \mathrm{~cm}$ 
a vjerojatno bi bio i veći broj grobova sa ostacima spaljenih kostiju pokojnika. Grob 37 te nakupine keramičkih posuda istočno od iskopa upućivale su na to da se groblje nastavlja na tu stranu, prema prostoru gdje je danas prilazna cesta, između čestica 748/2 i 747/3. Cijela ispuna svih grobnih jama (100\% uzorka) je sakupljena kako bi se mogao naknadno analizirati i svaki uzorak je označen. U brojnim grobnim jamama, osim gara vrlo često vrlo male, nedovoljne količine za analizu ${ }^{14} \mathrm{C}$, nije zabilježen nikakav drugi sadržaj, pa u njima nisu nađene niti čestice ljudskih kostiju. Prema pronađenome materijalu razvidno je da je veći dio predmeta bio spaljen zajedno s pokojnikom, a da je dio očito korišten kod ispraćaja, blagovanja te je tako unijet u grob. Materijal s istraživanja se čuva u prostorijama Arheološkoga zavoda Filozofskoga fakulteta u Sveučilišta u Zagrebu i u Gradskome muzeju u Sisku.

Iz ispune tri groba (grobovi 31, 32 i 37) izuzeti su uzorci ugljena, kao ostatka pogrebne lomače, za odredbu apsolutne starosti nalaza AMS metodom radioaktivnoga izotopa ugljika ${ }^{14} \mathrm{C}$. Rezultati su potvrdili dataciju prema arheološkim predmetima iz nekropola od 1. do 3. st. Za grob 31 konvencionalna ${ }^{14} \mathrm{C}$ starost uzorka, uz provedenu korekciju pomoću ${ }^{13} \mathrm{C}$, iznosi $1930 \pm 30 \mathrm{BP}$, za grob 34 iznosi 1840 \pm 30 BP, dok za grob 37 iznosi 1990 \pm 30 BP.' Rezultati kalibracije uzoraka za sva tri groba dani su unutar $1 \sigma$ i $2 \sigma$ intervala, što ukazuje da se starost uzoraka nalazi unutar danoga intervala pouzdanosti s relativnom vjerojatnošću $68.2 \%$ i $95.4 \%$. Dobiveni kalibracijski rezultati za uzorke iz groba 31 iznose 50-89 cal AD (1900-1861 cal BP) za $1 \sigma$ te 4-130 cal AD (1946-1820 cal BP) za 20, za uzorke iz groba 34 iznose 133-216 cal AD (1817-1734) za 16, 86-242 cal AD (1864-1708 cal BP) za $2 \sigma$ te za uzorke iz groba 37 iznose 2 cal BC - 30 cal AD (1951-1920 cal BP) za $1 \sigma$ te $49 \mathrm{cal} \mathrm{BC}-72$ cal AD (1998-1878 cal BP) za $2 \sigma$ interval.

Antropološkom analizom obuhvaćen je dvadeset i jedan grob iz sjeverozapadne nekropole u Sisku. Osteološki materijal je stabiliziran, očišćen i analiziran u prostorijama Ureda za forenzične znanosti Sveučilišta u Zagrebu. Spaljeni osteološki materijal potječe iz dvije urne (grobovi 1 i 2), dok ostali materijal predstavlja ostatke spaljenoga sadržaja s lomače sasutih u grobne jame. Antropološka analiza provedena je na materijalu iz pojedinoga groba. Ukoliko je količina materijala omogućavala, osteološki materijal iz svakoga groba izvagan je i prosijan te je upisana masa prema frakcijama sita: $F_{1}-10 \mathrm{~mm}, F_{2}-5 \mathrm{~mm} \mathrm{i} F_{3}-3 \mathrm{~mm}$. Materijal je analiziran standardnom makromorfološkom analizom. Zbog jače fragmentacije materijala kao sekundarna metoda odredbe spola korištena je morfometrijska metoda, mjerenje debljine dijafiza dugih kostiju, prvenstveno natkoljenične, goljenične i nadlaktične kosti. Slaba očuvanost i mali broja uzoraka bili su presudni za izbor histološke metode odredbe doživljene starosti, uz tehniku svjetlosne mikroskopije. Osteološki materijal iz svake urne i grobne jame pregledan je makroskopski te je tako učinjena standardna antropološka analiza (Buikstra, Ubelaker

1 Report of radiocarbon dating no. 536779, 536780, 536781. Beta Analytic Inc., testing laboratory. higher than the bottom to which the probe was lowered. It can be said that there were several graves at that position and that most of them were totally destroyed; there would probably be even larger number of graves with the remains of the burnt bones of the deceased. Grave 37 and the accumulations of ceramic vessels east of the excavated area indicated that the cemetery continues on that side, towards the area where the access road is today, between plots $748 / 2$ and $747 / 3$. The entire filling of all grave pits ( $100 \%$ of the sample) was collected so that it could be subsequently analyzed and each sample was labeled. In many grave pits, apart from soot (very often minimal quantities, insufficient for ${ }^{14} \mathrm{C}$ analysis), no other contents were recorded, including human bone particles. According to the found material, it is evident that most of the found items were burned together with the deceased, and a part was obviously used for funerals, meals and was thus put into the grave. The material from the research is kept in the Archaeological Institute of the Faculty of Humanities and Social Sciences at the University of Zagreb and in the Sisak Municipal Museum.

As the remains of a funeral pyre, coal samples were taken from the filling of three graves (graves 31, 32 and 37) to determine the absolute age of the findings by the AMS radioactive carbon isotope ${ }^{14} \mathrm{C}$ method. The results confirmed the dating according to archaeological objects from the necropolis from the $1^{\text {st }}$ to the $3^{\text {rd }}$ century. For grave 31 , the conventional ${ }^{14} \mathrm{C}$ radiocarbon age of the sample, with ${ }^{13} \mathrm{C}$ correction, is $1930 \pm 30 \mathrm{BP}$, for grave 34 , it is $1840 \pm 30 \mathrm{BP}$, while for grave 37 it is $1990 \pm 30 \mathrm{BP}$. The samples' calibration results for all three graves were given within the $1 \sigma$ and $2 \sigma$ interval, indicating that the samples' age is within the given confidence interval with a relative probability of $68.2 \%$ and $95.4 \%$. The obtained calibration results for samples from the grave 31 are 50-89 cal $A D$ (1900-1861 cal BP) for 16, 4-130 cal AD (1946-1820 cal BP) for $2 \sigma$, for samples from the grave 34 are 133-216 cal AD (1817-1734) for $1 \sigma, 86-242 \mathrm{cal}$ AD (1864-1708 cal BP) for $2 \sigma$, and for samples from the grave 37 are $2 \mathrm{cal} \mathrm{BC}-30 \mathrm{cal} A D$ (1951-1920 cal BP) for $1 \sigma, 49$ cal BC -72 cal AD (1998-1878 cal BP) for $2 \sigma$ interval.

The anthropological analysis included twenty-one graves from the northwestern necropolis in Sisak. Osteological material was stabilized, cleaned, and analyzed in the Forensic science Office, University of Zagreb. The burned osteological material comes from two urns (graves 1 and 2), while the rest of the material represents the remains of the burned contents from the pyre buried in the grave pits. Anthropological analysis was performed on the material from each individual grave. If the amount of material allowed, the osteological material from each grave was weighed and sieved, and the mass was recorded according to the sieve fractions: $F_{1}-10 \mathrm{~mm}, F_{2}-5 \mathrm{~mm}$ and $F_{3}-3 \mathrm{~mm}$. The material was analyzed by standard macromorphological analysis. Due to the stronger fragmentation of the material, the morphometric method was used as a secondary method of sex determination, measuring the thickness of

1 Report of radiocarbon dating no. 536779, 536780, 536781. Beta Analytic Inc., testing laboratory. 
1994; Kleppinger 2006; Blau, Ubelaker 2012 ; Cerezo-Roman et al. 2017). Određen je temperaturni raspon gorenja za osteološki materijal svakoga groba prema specifičnoj boji određenoj iz Munsellova sustava boja (Munsell 2000). Zbog malog broja uzoraka i visoke razine fragmentacije, određivanje doživljene starosti izvedeno je modificiranom histološkom metodom prema Kerley, uz upotrebu regresijske formule (Kerley 1965; Kerley, Ubelaker 1978; Hincak et al. 2007). Osnovni princip ove histološke metode jest utvrditi broj osteonskih sustava na jedinici površine i odrediti njihovo stanje, zajedno s postotkom lamelarne kosti. Za uspješnost ove metode iznimno je važno izabrati uzorke dijafiza natkoljenične, goljenične ili nadlaktične kosti koji nisu gorjeli na izuzetno visokim temperaturama i dobro su očuvali strukturu kosti. Svi kalcinirani uzorci, oni koji su spaljeni na temperaturi višoj od 900 ili $1000{ }^{\circ} \mathrm{C}$, izuzimaju se za histološku analizu. Prema potrebi, uzorci dijafiza su stabilizirani uklapanjem u akrilnu smolu te su pripremljeni za rezanje na mikrotomu (Minitom, Struers) u rasponu debljina 10-25 $\mu \mathrm{m}$ i polirani na Labopolu-1 (Struers). Mikroskopska analiza provedena je pri standardnim povećanjima: $10 \times 10,20 \times 10,40 \times 10$ (Olympus, CX41RF), a fotomikrografi su snimljeni digitalnom kamerom (Olympus 5050 C-Zoom). Ukupno je pripremljen 41 histološki pripravak iz fragmenata dijafize patele, tibije i humerusa te fragmenata dijafize dugih kostiju životinja.

\section{REZULTATI}

Makroskopskom analizom obuhvaćen je dvadeset jedan paljevinski grob, histološkom metodom analize njih sedamnaest, a morfometrijskom osamnaest iz sjeverozapadne nekropole u Sisku. Masa spaljenoga koštanog materijala za pojedini grob rijetko je prelazila $100 \mathrm{~g}$, izuzetak je materijal iz grobova 2 i 4 s masom 163,93 g i 153,66 g (tab. 1). Masa od $50 \mathrm{~g}$ do $100 \mathrm{~g}$ utvrđena je za materijal iz grobova 21 i C s masom 71,25 g i 84,48 g, a od $30 \mathrm{~g}$ do $50 \mathrm{~g}$ za materijal iz grobova 14 i 37 (tab. 1). Raspon masa od $20 \mathrm{~g}$ do $30 \mathrm{~g}$ utvrđen je za materijal iz grobova: 1, 3, 15, 20, 31 i 34. Masa materijala u rasponu od $10 \mathrm{~g}$ do $20 \mathrm{~g}$ utvrđena je za grobove: $9,16,30$ i 45 . Konačno, vrlo niska masa, koja ne prelazi $10 \mathrm{~g}$, utvrđena je za grobove: 10, 12, 17, 18 i 40. Prikaz masenih frakcija za pojedini grob pokazuje visoku fragmentiranost materijala (graf 1). Materijal iz grobova vrlo niske mase poput grobova 10, 12, 17 i 18 nije prosijavan. Boja koštanih fragmenata nalazi se u rasponu od crne, smeđe, tamnije sive do sive za očuvane fragmente trabekularne kosti i unutarnjeg dijela dijafiza dugih kostiju te fragmente krune i korijena zuba. Boja čvrste tvari kosti je svjetlija: svijetlo smeđa, svjetlo siva, blijedo žuta i žućkasto bijela do bijela (tab. 1). Izdvajaju se svjetlije boje koštanoga materijala iz urni, u grobovima 1 i 2 (tab. 1) te je taj materijal bolje očuvan. Većina fragmenata očuvanih $u F_{1}$ frakciji dovoljno su dugi da pokazuju karakteristične deformacije kostiju uslijed djelovanja visoke temperature (sl. 1-2).

Tako dijafize nadlaktične, goljenične i natkoljenične kosti pokazuju deformacije u smislu polumjesečastih pukotina (sl. 1), dok ostali osteološki elementi pokazuju deformacije izvijanja i skupljanja (sl. 2). the diaphysis of long bones, primarily the femur, tibia and humerus. Poor preservation and a small number of samples were crucial for choosing the histological method of determining the age at death, along with the technique of light microscopy. Osteological material from each urn and grave pit was examined macroscopically and a standard anthropological analysis performed (Buikstra, Ubelaker 1994; Kleppinger 2006; Blau, Ubelaker 2012 ; Cerezo-Roman et al. 2017). The burning temperature range for the osteological material in each grave was determined according to a specific colour chosen according to Munsell's colour system (Munsell 2000). Due to the small number of samples and their high level of fragmentation, the determination of age at death was perfomed by a modified histological method according to Kerley, using regression formula (Kerley 1965; Kerley, Ubelaker 1978; Hincak et al. 2007). The basic principle of this microscopic method is to determine the number of osteon systems per unit area and determine their condition, along with the percentage of lamellar bone. For the success of this method, it is extremely important to choose samples of the diaphysis of the femoral, tibial or humeral bone that didn't burn at extremely high temperatures and had the bone structure well preserved. All calcined samples, those burned at a temperature higher than $900-1000^{\circ} \mathrm{C}$, are taken for histological analysis. If necessary, diaphysis samples were stabilized by fitting into acrylic resin and prepared for cutting on a microtome (Minitom, Struers) in the thickness range of 10-25 $\mu \mathrm{m}$ and polished on Labopol-1 (Struers). Microscopic analysis was performed at standard increments: $10 \times 10,20 \times 10,40 \times 10$ (Olympus, CX41RF), and photomicrographs were recorded with a digital camera (Olympus 5050 C-Zoom). A total of 41 histological preparations were prepared from fragments of the diaphysis of the patella, tibia and humerus and fragments of the diaphysis of the long bones of animals.

\section{RESULTS}

Twenty-one cremation graves were included in the macroscopic analysis, seventeen in the histological method and eighteen in the morphometric method, all of them from the northwestern necropolis in Sisak. The mass of burned bone material for an individual grave rarely exceeded 100 grams, except for material from graves 2 and 4, with a mass of $163.93 \mathrm{~g}$ and $153.66 \mathrm{~g}$ (Tab. 1). The weight from $50 \mathrm{~g}$ to $100 \mathrm{~g}$ was determined for the material from graves 21 and $C$ with the weight of $71.25 \mathrm{~g}$ and $84.48 \mathrm{~g}$, and from $30 \mathrm{~g}$ to $50 \mathrm{~g}$ for the material from graves 14 and 37 (Tab. 1). The range of masses from $20 \mathrm{~g}$ to $30 \mathrm{~g}$ was determined for the material from graves 1, 3, 15, 20, 31 and 34. The range of masses from $10 \mathrm{~g}$ to $20 \mathrm{~g}$ was determined for the material from graves $9,16,30$ and 45 . Finally, a very low mass, not exceeding $10 \mathrm{~g}$, was determined for graves $10,12,17,18$ and 40 . The display of mass fractions for each grave shows high fragmentation of materials (Graph 1). Material from very low mass graves such as graves 10, 12,17 and 18 was not sieved. The color of the bone fragments ranges from black, brown, darker gray to gray, for preserved fragments of the trabecular bone and the inner part of the diaphysis of long bones and fragments of 


\begin{tabular}{|c|c|c|c|c|c|}
\hline $\begin{array}{l}\text { Grob } \\
\text { broj / } \\
\text { Grave } \\
\text { number }\end{array}$ & $\begin{array}{c}\text { Masa / } \\
\text { Mass }(\mathrm{g}) \\
\left(\mathrm{F}_{1}+\mathrm{F}_{2}+\mathrm{F}_{3}\right)\end{array}$ & $\begin{array}{l}\text { Spol / } \\
\text { Sex }\end{array}$ & $\begin{array}{l}\text { Doživljena starost / } \\
\text { Age at death }\end{array}$ & $\begin{array}{l}\text { Boja spaljenih kosti } \\
\text { (prema Munsellu) / } \\
\text { Colour of burned bones } \\
\text { (according to Munsell) }\end{array}$ & $\begin{array}{l}\text { Životinjske kosti / } \\
\text { Animal bones }\end{array}$ \\
\hline 1 & 25,05 & $\mathrm{~F}$ ? & $40-50$ & $2.5 Y 8 / 1,2.5 Y 8 / 2$ & ptica / bird (Aves) \\
\hline 2 & 163,93 & $M ?$ & $30-35$ & $2.5 Y 8 / 1,2.5 Y 6 / 2,2.5 Y 2.5 / 1,2.5 Y 6 / 1$ & $\begin{array}{c}\text { mali preživači / small ruminant } \\
\text { (Capra hircus, L., Ovis aries, L.) }\end{array}$ \\
\hline 3 & 25,82 & $\mathrm{~F} ?$ & $20-30$ & $2.5 Y 8 / 1,2.5 Y 4 / 1$ & $\begin{array}{l}\text { mali glodavac / small rodent } \\
\text { (Rodentia) }\end{array}$ \\
\hline 4 & 153,66 & $\begin{array}{l}A-M ? \\
B-F ?\end{array}$ & $\begin{array}{c}\text { A } 30-40, \text { B } \\
\text { odrasla / adult }\end{array}$ & $2.5 Y 8 / 2,2.5 Y 7 / 1,2.5 Y 5 / 1,2.5 Y 8 / 3$ & - \\
\hline 9 & 17,94 & $M ?$ & $20-30$ & $5 Y 8 / 1,5 Y 5 / 1,2.5 Y 8 / 1$ & - \\
\hline 10 & 1,10 & - & $?$ & $2.5 Y 8 / 1$ & - \\
\hline 12 & 6,35 & - & $\begin{array}{c}\text { odrasla osoba / } \\
\text { adult }\end{array}$ & $5 Y 6 / 1,2.5 Y 7 / 2$ & - \\
\hline 14 & 38,31 & $\mathrm{~F} ?$ & $20-30$ & $2.5 Y 2.5 / 1,2.5 Y 8 / 1$ & $\begin{array}{c}\text { mali preživači / small ruminants } \\
\text { (Capra hircus, L., Ovis aries, L.) }\end{array}$ \\
\hline 15 & 25,88 & - & $\begin{array}{c}\text { odrasla osoba / } \\
\text { adult }\end{array}$ & $\begin{array}{c}2.5 Y 8 / 1,2.5 Y 8 / 2,2.5 Y 7 / 1,2.5 Y 7 / 4 \\
2.5 Y 4 / 1\end{array}$ & - \\
\hline 16 & 17,65 & - & $\begin{array}{c}\text { odrasla osoba / } \\
\text { adult }\end{array}$ & $2.5 Y 8 / 2,2.5 Y 7 / 3$ & $\begin{array}{c}\text { preživači / ruminant } \\
\text { (Ruminantia) }\end{array}$ \\
\hline 17 & 1,31 & - & $\begin{array}{l}\text { humani uzorak / } \\
\text { human sample }\end{array}$ & $2.5 Y R 8 / 1$ & - \\
\hline 18 & 3,68 & - & $\begin{array}{l}\text { dijete / } \\
\text { child }\end{array}$ & 10YR8/1, 10YR8/2 & - \\
\hline 20 & 24,76 & $\mathrm{~F}$ ? & $20-30$ & $2.5 Y 7 / 2,2.5 Y 6 / 1$ & - \\
\hline 21 & 71,25 & - & $25-30$ & $2.5 Y 8 / 3,2.5 Y 5 / 1,2.5 Y 6 / 2,2.5 Y 6 / 1$ & - \\
\hline 30 & 15,93 & $M ?$ & $30-40$ & $2.5 Y 8 / 1,2.5 Y 6 / 1,2.5 Y 5 / 1$ & - \\
\hline 31 & 24,25 & - & $\begin{array}{l}\text { dijete / } \\
\text { child }\end{array}$ & $2.5 Y 8 / 1,2.5 Y 7 / 1$ & - \\
\hline 34 & 22,69 & - & $30-40$ & $2.5 Y 8 / 1,2.5 Y 8 / 2,2.5 Y 7 / 1,5 Y 4 / 1$ & - \\
\hline 37 & 35,07 & $M ?$ & $35-45$ & $2.5 Y 8 / 1,2.5 Y 5 / 1,2.5 Y 8 / 2$ & - \\
\hline 40 & 8,98 & - & $\begin{array}{c}\text { odrasla osoba / } \\
\text { adult }\end{array}$ & $2.5 Y 8 / 1,2.5 Y 6 / 1$ & - \\
\hline 45 & 11,46 & - & $\begin{array}{c}\text { odrasla osoba / } \\
\text { adult }\end{array}$ & $\begin{array}{c}2.5 Y 8 / 1,2.5 Y 7 / 1,2.5 Y 6 / 1,2.5 Y 5 / 1, \\
2.5 Y 2.5 / 1\end{array}$ & - \\
\hline C & 84,48 & $\mathrm{M} ?$ & $40-45$ & $2.5 Y 8 / 1,2.5 Y 7 / 1,2.5 Y 7 / 2,2.5 Y 5 / 2$ & - \\
\hline
\end{tabular}

Tab. 1 Rezultati makroskopske i histološke metode analize (sjeverozapadna nekropola Siscije). Legenda: $M=$ masculinum; $\mathrm{F}=$ femininum (izradila: Z. Hincak Daris)

Tab. 1 Results of macroscopic and histological method of analysis (northwestern necropolis of Siscia). Legend: $M=$ masculinum; $F=$ femininum (made by: Z. Hincak Daris)

Makromorfološka metoda obuhvatila je pregled koštanih ostataka i morfometrijsku analizu fragmenata natkoljenične i goljenične kosti. Slaba očuvanost fragmenata i općenito mala masa materijala iz grobova nisu omogućili dovoljno podataka koje inače pruža ovaj tip analize. Ipak, treba izdvojiti materijal iz grobova 2, 4, 21 i groba C koji obuhvaća fragmente lubanje $s$ djelomice očuvanim šavovima, fragmente luka i tijela kralježaka, rebara, fragmente epifiza nadlaktične kosti, proksimalne dijelove lakatne kosti, glave palčane kosti, lopatice, sjedne kvrge i članke prsta dobre očuvanosti (sl. 3).

Materijal iz većine grobova pripadao je odraslim osobama (grobovi 1, 2, 3, 4, 9, 14, 15, 20, 21, 30, 37, 40, 45 i C), bez mogućnosti preciznije odredbe doživljene starosti makromorfološkom metodom. Treba spomenuti grob 34 the crown and root of the tooth. The color of the cortex is lighter: light brown, light gray, pale yellow, and yellowish white to white (Tab. 1). The lighter colors of the bone material from the urn stand out, in graves 1 and 2 (Tab. 1), and this material is better preserved. Most of the fragments preserved in the $F_{1}$ fraction are long enough to show characteristic bone deformations, due to the influence of high temperature (Figs. 1-2).

The diaphysis of the humeral, tibial and femoral bone show deformities in terms of crescent-shaped cracks (Fig. 1), while other osteological elements show deformities of flexion and contraction (Fig. 2).

The macromorphological method included examination of bone remains and morphometric analysis of fragments of the femoral and tibial bone. Poor level of pres- 


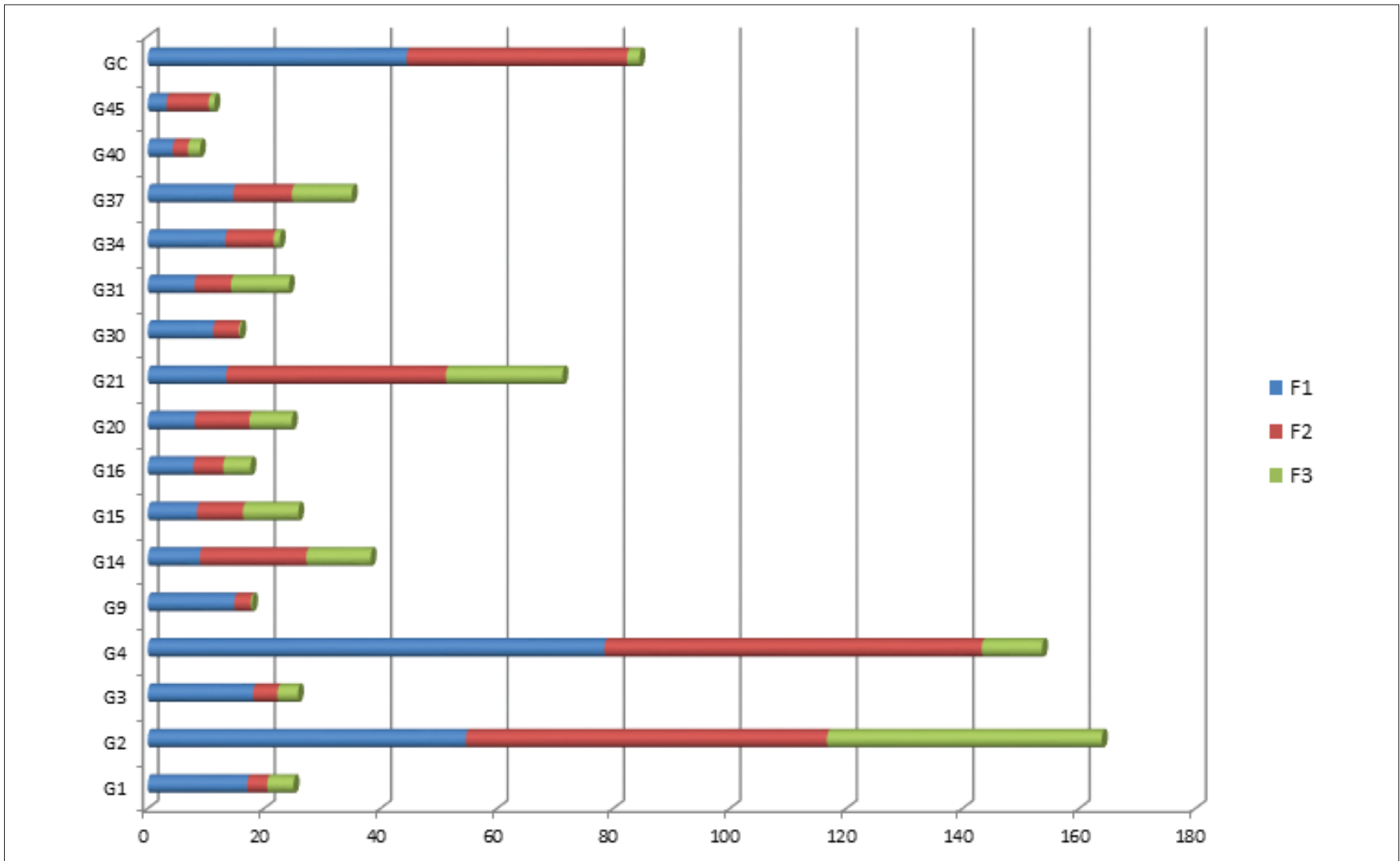

Graf 1 Prikaz masenih frakcija u gramima $\left(F_{1}-10 \mathrm{~mm} ; F_{2}-5 \mathrm{~mm} ; \mathrm{F}_{3}-3 \mathrm{~mm}\right.$ ) za pojedinačni grob (sjeverozapadna nekropola Siscije) (izradila: Z. Hincak Daris)

Graph 1 Display of mass fractions $\left(F_{1}-10 \mathrm{~mm} ; F_{2}-5 \mathrm{~mm} ; F_{3}-3 \mathrm{~mm}\right.$ ) for individual graves (northwestern necropolis of Siscia) (made by: Z. Hincak Daris)

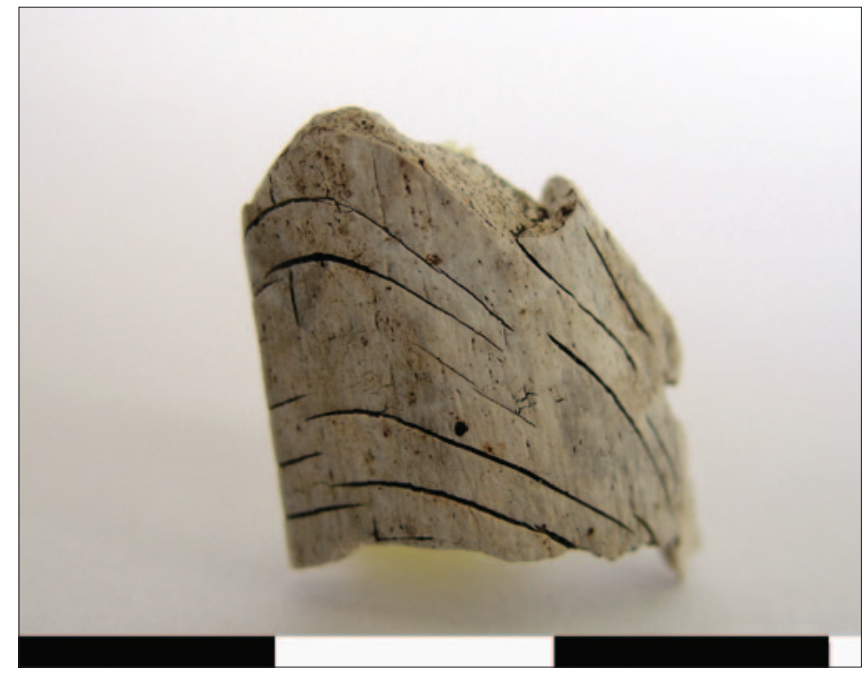

SI. 1 Zaostala polumjesečasta puknuća na fragmentu dijafize nadlaktične kosti, muška osoba?, doživljena starost 35-45 godina, grob 37 (sjeverozapadna nekropola Siscije) (snimila: Z. Hincak Daris)

Fig. 1 The residual curved transverse fractures of humeral diaphysis fragment, male?, age at death 35-45 years, grave 37 (northwest necropolis of Siscia) (photo by: Z. Hincak Daris)

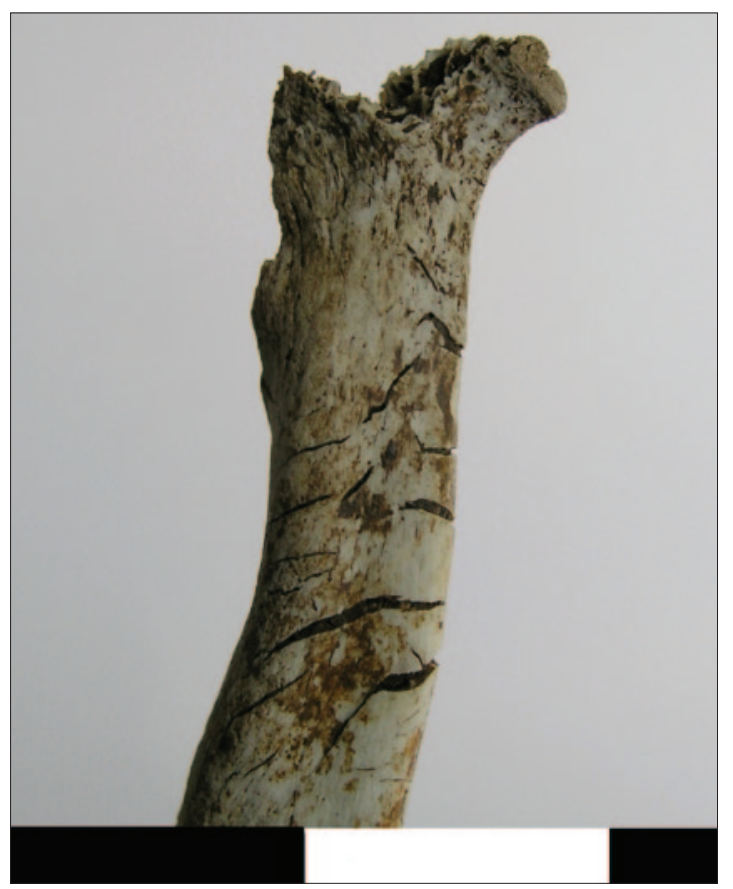

SI. 2 Proksimalni dio drugoga ili trećega lijevog rebra s vidljivim transverzalnim pukotinama, muška osoba?, doživljena starost 30-35 godina, grob 2 (sjeverozapadna nekropola Siscije) (snimila: Z. Hincak Daris)

Fig. 2 Proximal part of second or third left rib with distinct transverse fractures, male?, age at death 30-35 years, grave 2 (northwest necropolis of Siscia) (photo by: Z. Hincak Daris) 


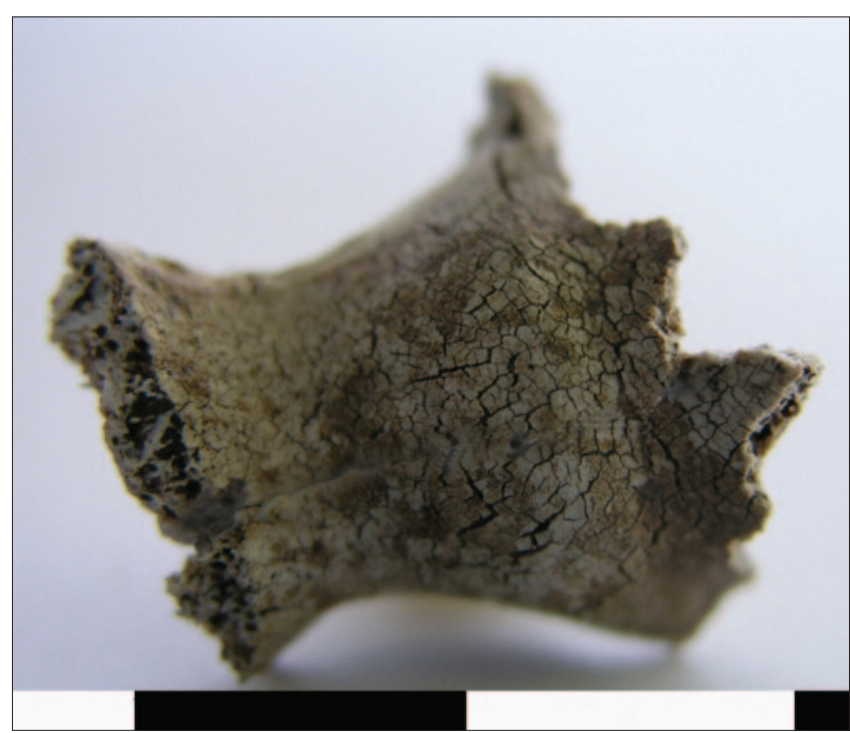

SI. 3 Spaljeni fragment distalne epifize desne nadlaktične kosti (trochlea humeri), muška osoba?, doživljena starost 30-35 godina, grob 2 (sjeverozapadna nekropola Siscije) (snimila: Z. Hincak Daris)

Fig. 3 Burnt fragment of the distal epiphysis of the right humeral bone (trochlea humeri), male?, age at death 30-35, grave 2 (northwest necropolis of Siscia) (photo by: Z. Hincak Daris)

u kojem su sav koštani materijal predstavljali fragmenti dijafiza dugih kostiju bez posebnih obilježja, no zahvaljujući očuvanim fragmentima trabekularne kosti na kratkim dijelovima epifiza neosporno je utvrđeno humano podrijetlo. Dva su groba s koštanim fragmentima djece, 18 i 31. Materijal iz groba 18 je vrlo skroman, s masom od 3,68 g koja obuhvaća fragment duge kosti dužine $10 \mathrm{~mm}$, kost lubanje i tri fragmenta kosti. Makromorfološkom analizom moglo se tek pretpostaviti humano podrijetlo uzorka. Drugačiji je slučaj s materijalom iz groba 31. Masa uzoraka bila je znatno veća i obuhvaćala je prepoznatljive dijelove humanih osteoloških elemenata. Osim fragmenata dijafiza natkoljenice ili nadlaktice te fragmenata plosnate kosti lubanje, očuvani fragmenti ivera i luka kralješka upućivali su na koštane ostatke djeteta. Ovom klasičnom, antropološkom analizom nije bilo moguće sa sigurnošću utvrditi humano podrijetlo niti doživljenu starost za materijal iz grobova 12 i 40 koji je uključivao samo fragmente dijafiza dugih kostiju. Vrlo niska masa materijala od 1,31 g iz groba 17 bila je dovoljna za utvrđivanje humanoga podrijetla na što su upućivali očuvani fragmenti nosne kosti i kosti lubanje. Za materijal iz groba 10 niske mase od 1,10 g te očuvanim sitnim fragmentima kostiju lubanje i kratke, oštećene dijafize kosti, nije bilo moguće odrediti humano ili animalno podrijetlo uzoraka. Grob 4 je jedini čiji je materijal sadržavao ostatke dvije osobe. Gotovo sav materijal pripadao je osobi A. Dobro je očuvano šest fragmenata kostiju lubanje, najveći koji mjeri 29 × 25,6 mm i dio je sljepoočne kosti na kojem su vidljivi potpuno otvoreni šavovi (sutura occipito-mastoidea et sutura parieto-mastoidea) i tri fragmenta krune zuba stalne denticije. Očuvano je pola tijela trećega vratnog kralješka, tri fragmenta dijafize nadlaktične kosti ervation of the fragments and the generally small mass of material from the graves didn't provide enough data, which is otherwise provided by this type of analysis. However, material from graves $2,4,21$ and grave $C$ should be singled out, because it includes good preserved fragments of the skull with partially preserved sutures, fragments of the arch and body of the vertebrae, ribs, fragments of the humeral epiphyses, proximal parts of the ulnar bone, head of radial bone, scapular bone, ischial tuberosity and phalanges (Fig. 3).

The material from most of the graves belonged to adults (graves 1, 2, 3, 4, 9, 14, 15, 20, 21, 30, 37, 40, 45 and C), without the possibility of a more precise determination of the age at death by the macromorphological method. The grave 34 should be mentioned, in which all the bone material was represented by fragments of the diaphysis of long bones, without special features, but thanks to the preserved fragments of trabecular bone on the short parts of the pineal gland, human origin has been indisputably proven. There are two graves with bone fragments of children, 18 and 31 . The material from grave 18 is very modest, weighing $3.68 \mathrm{~g}$, which includes a fragment of long bone $10 \mathrm{~mm}$ long, a cranial bone and three bone fragments. Macromorphological analysis could only assume the human origin of the sample. The case is different with the material from grave 31 , because the mass of the samples was significantly larger and included recognizable parts of human osteological elements. In addition to fragments of the diaphysis of femoral or humeral bone and fragments of the cranial flat bone, the preserved fragments of patellar bone and the vertebral arch referred to the bone remains of the child. With this classical, anthropological analysis, it wasn't possible to determine with certainty the human origin or the age at death for the material from graves 12 and 40 , which included only fragments of long-bone diaphysis. A very low mass of material of $1.31 \mathrm{~g}$ from grave 17 was sufficient to establish human origin, as indicated by the preserved fragments of nasal bone and cranial bone. For material from grave 10 of low mass of $1.10 \mathrm{~g}$ and preserved tiny fragments of cranial bone and short, damaged bone diaphysis, it wasn't possible to determine the human or animal origin of the samples. Grave 4 is the only one whose material contained the remains of two people. Almost all the material belonged to person A. Six fragments of the cranial bone are well preserved, the largest measuring $29 x$ $25.6 \mathrm{~mm}$ and is the part of the temporal bone, where fully open cranial sutures are visible (sutura occipito-mastoidea et sutura parieto-mastoidea) and three fragments of the crown teeth of permanent dentition. The following is well preserved: half of the body of the third cervical vertebra, three fragments of the diaphysis of the humeral bone (whose thickness is in the range of 3-4.5 mm), four samples of the diaphysis of the radial bone, part of the right radial bone with preserved fragment of radial tuberosity (tuberositas radii), fragment of the head of the right radial bone, fragment of the proximal diaphysis of the ulnar bone with preserved ulnar tuberosity (tuberositas ulnae), six fragments of the diaphysis of the tibial bone, whose thickness is in the range of $5-8.5 \mathrm{~mm}$ and a fragment of the proximal 
čija se debljina nalazi u rasponu 3-4,5 mm, četiri uzorka dijafize palčane kosti, dio desne palčane kosti s očuvanim fragmentom hrapavosti (tuberositas radii), fragment glave desne palčane kosti, fragment proksimalne dijafize lakatne kosti s očuvanom hrapavosti (tuberositas ulnae), šest fragmenata dijafize goljenične kosti čija se debljina nalazi u rasponu 5-8,5 mm te fragment proksimalne epifize lisne kosti. Prema robusnosti uzoraka i morfometrijskih vrijednosti debljina za nadlaktične i natkoljenične fragmente dijafiza moguće je pretpostaviti muški spol osobe. Od osobe $B$ očuvana su tri kraća fragmenta kostiju lubanje, osam fragmenata dijafiza dugih kostiju te fragment proksimalne dijafize lakatne kosti s očuvanom hrapavosti. Uzorci osobe B odvojeni su od ostataka osobe A prema izraženoj gracilnosti, što je značajka ženskoga spola, a zbog razvijene hrapavosti na dijafizi lakatne kosti moguće je tvrditi da su pripadali odrasloj osobi.

Standardni znakovi prema kojima bi se makromorfološkom metodom s visokom vjerojatnošću utvrdio spol na osteološkim elementima nisu očuvani na materijalu iz nekropole. Bolje očuvani koštani fragmenti iz grobova 2, 4 i 37 ukazuju na robusnost struktura osteoloških elemenata. Takvi uzorci iz groba 2 uključuju fragmente acromiona lopatice, distalnog kondila desne nadlaktične kosti, sjedne kvrge lijeve bočne kosti, drugoga ili trećega proksimalnog fragmenta članka prsta, dok su uzorci iz groba 4 osobe A obuhvatili fragmente glave desne palčane kosti, proksimalne dijafize lakatne kosti s očuvanom hrapavosti (tuberositas ulnae) i fragment glave palčane kosti (sl. 3). Većinu očuvanoga materijala iz grobova čine fragmenti dijafiza dugih kosti. Fragmenti dijafiza natkoljenične kosti pokazuju različit raspon razvoja trnaste linije (linea aspera), od nježno izražene (grobovi 1, 3, 14 i 20), srednje izražene (grobovi 21, 34, 37, 45) do naglašene ili snažno razvijene (grobovi 2, 4A, 9, 30, C). No, kako je stupanj razvoja trnaste linije odraz razvijenosti pojedinih hvatišta mišića, odnosno tjelesne aktivnosti pojedinca, izražajnost linije nije pouzdan znak za utvrđivanje spola. Morfometrijske vrijednosti za debljinu natkoljenične, goljenične i nadlaktične kosti te čeone kosti pomogle su pretpostaviti spol osobe (tab. 1-2). Stoga je spol za sve ostatke osoba u grobovima, četiri ženske osobe i šest muških osoba pretpostavljen, no ne i siguran.

Visoko fragmentirani ostaci zuba stalne denticije utvrđeni su u materijalu iz grobova 2, 3, 4, 14, 20 i grobu C. Dvanaest fragmenata kruna zuba predstavljaju ostatke kutnjaka i pretkutnjaka, jedan je fragment krune očnjaka, a od korijena zuba ukupno je očuvano sedam fragmenata. Patološke promjene vidljive su na uzorku fragmenta dijafize goljenice s izraženim aktivnim periostitisom koji mjeri u dužinu 14,2 mm. Uzorak je dio materijala iz groba 37, muške osobe doživljene starosti 35-45 godina (sl. 4).

Histološka metoda analize doživljene starosti ljudi izvedena je na fragmentima dijafiza nadlaktične, natkoljenične i goljenične kosti (sl. 5). U tab. 2 navedeni su segmenti osteoloških elemenata koji su kao fragmenti izdvojeni za histološku analizu, njihov broj te broj ukupnih preparata epiphysis of the fibular bone. According to the robustness of the samples and the morphometric values of the thicknesses for the humeral and femoral bone fragments of the diaphysis, it is possible to assume the male gender of the person. Three shorter fragments of the cranial bone, eight fragments of the diaphysis of the long bones and a fragment of the proximal diaphysis of the ulnar bone with preserved tuberosity have been preserved from person $B$. Samples of person B were separated from the remains of person A according to pronounced gracefulness, which is a characteristic of the female gender, and due to the developed tuberosity on the diaphysis of the ulnar bone it is possible to claim that they belonged to an adult.

Standard signs, according to which the sex on osteological elements would be determined with a high probability by a macromorphological method, have not been preserved on the material from the necropolis. Better preserved bone fragments from graves 2, 4 and 37 indicate the robustness of the structures of osteological elements. Such specimens from grave 2 include fragments of the acromion of the scapular bone, distal condyle of the right humeral bone, ischial tuberosity of the left hip bone, second or third proximal fragment of phalanx, while samples from grave 4 of person $A$ included fragments of the head of radial bone, proximal diaphysis of the ulnar bone with preserved tuberosity (tuberositas ulnae) and a fragment of the head of the radial bone (Fig. 3). Most of the preserved material from the graves consists of fragments of diaphysis of long bones. Preserved fragments of the diaphysis of the femoral bone show the range of development of the rough line (linea aspera), from gently pronounced (graves $1,3,14$ and 20), moderately pronounced (graves 21, 34, 37 and 45 ) to pronounced or strongly developed (graves 2 , $4 A, 9,30$ and C). However, as the degree of development of the rough line is a reflection of the development of individual muscle attachments, which refers to the physical activity of the individual, the expressiveness of the line is not a reliable sign for determining gender. Morphometric values for the thickness of the femoral, tibial and humeral bone, and the diplöe of the frontal bone helped to presuppose the gender (Tabs. 1-2). Therefore, gender for all the remains of persons in the graves (four females and six males) is presumed, but not certain.

Highly fragmented remains of permanent dentition teeth were found in material from graves 2, 3, 4, 14, 20 and grave $C$. Twelve fragments of tooth crowns represent the remains of molars and premolars, one fragment of canine crown, and 7 fragments of the tooth root have been preserved. Pathological changes are visible only on a sample of a fragment of the tibia's diaphysis with pronounced active periostitis, $14.2 \mathrm{~mm}$ long. The sample is part of a material from grave 37, a male aged at death 35-45 years (Fig. 4).

The histological method of analysis of the age at death was performed on fragments of the diaphysis of the humeral, femoral and tibial bone (Fig. 5). Tab. 2 shows the segments of osteological elements that were selected as fragments for histological analysis, their number and the number of total preparations for each grave. Out of a total of twenty-nine preparations, one was made from the 


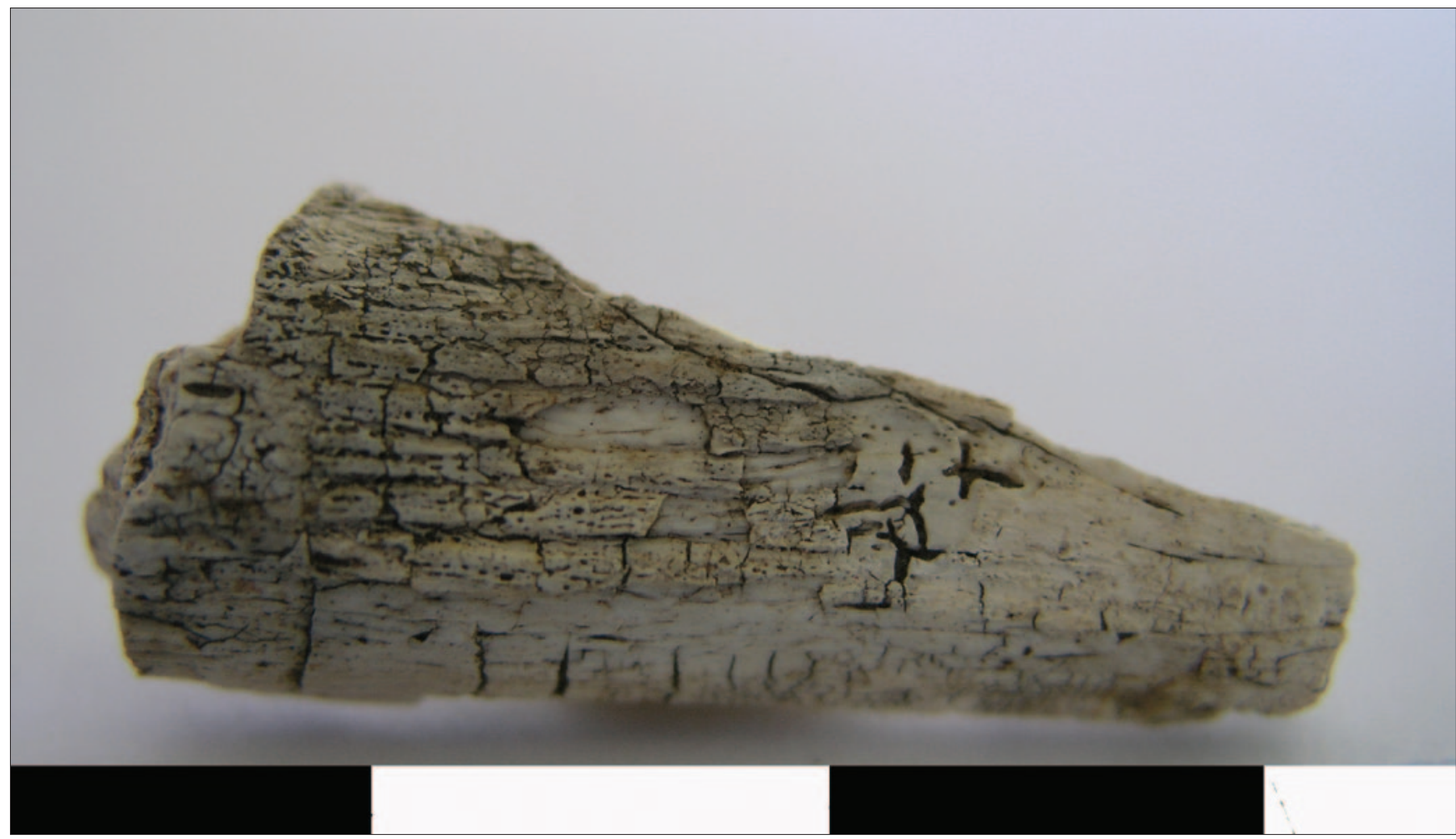

Sl. 4 Aktivni periostitis na fragmentu dijafize kosti goljenice, muška osoba ?, doživljena starost 35-45 godina, grob 37 (sjeverozapadna nekropola Siscije) (snimila: Z. Hincak Daris)

Fig. 4 Active periostitis on the fragment of tibial bone diaphysis, male?, age at death 35-45 years, grave 37 (northwest necropolis of Siscia) (photo by: Z. Hincak Daris)

za pojedini grob. Od ukupno dvadeset devet preparata, učinjen je jedan iz nadlaktične kosti, dvadeset dva za natkoljeničnu kost, četiri za kost goljenice i dva za duge kosti (tab. 1-2). Utvrđeni su uzorci dječjih kostiju iz fragmenta natkoljenične ili goljenične kosti iz groba 18 te fragmenta dijafize duge kosti iz groba 31, ukupno iz tri preparata. Učinjena su dva preparata iz dva oštećena fragmenta dugih kostiju čijom se analizom moglo utvrditi humano podrijetlo uzorka i doživljena starost u kategoriji odraslih osoba. Materijal iz grobova 4 (osoba B), 10 i 17 nije analiziran histološkom metodom jer materijal nije bio pogodan za pripremu mikroskopskih preparata. Pripremljeno je i analizirano šest preparata učinjenih iz fragmenata dijafiza dugih kosti životinja. Histološka analiza ispituje i utvrđuje stanje osteonskih sustava i njihovoga broja u odnosu na jedinicu površine. Mikroskopski uzorci vrlo mladih osoba pokazuju rijetke osteonske sustave i više lamelarne kosti, dok s godinama sustavi postaju sve koncentriraniji i gušći i $s$ vremenom se počinju deformirati.

Za uzorke većine odraslih osoba doživljena starost histološkom metodom određena je u rasponu od deset godina, no samo je iznimno, kada je očuvano više uzoraka dijafiza kosti, taj raspon skraćen za pet godina, za materijal iz grobova 2 i 21 . Sadržaj urni analiziran je iz grobova 1 i 2 i oni predstavljaju najbolje očuvan osteološki materijal, dok je osteološki materijal pohranjen u grobnu jamu slabije očuvanosti. Raspon doživljene starosti moguće je podijeliti na fazu infans - dvoje djece do 14 godina (grobovi 18 humeral bone, twenty-two for the femoral bone, four for the tibial bone and two for the long bones (Tabs. 1-2). Children's bone samples were determined from a fragment of the femoral or tibial bone from grave 18 and a fragment of the long bone diaphysis from grave 31, from a total of three preparations. Two preparations were made from two damaged fragments of long bones, the analysis of which could determine the human origin of the sample and the age at death in the category of adults. The material from graves 4 (person B), 10 and 17 was not analyzed by histological method, because the material was not suitable for the preparation of microscopic preparations. Six preparations made from fragments of diaphysis of long bones of animals were prepared and analyzed. The histological analysis examines and determines the state of osteon systems and their number in relation to the unit area. Microscopic samples of very young people show more lamellar bone and rare osteon systems, and with age, they will become more concentrated and denser and will begin to deform.

For samples of most adults, the age at death range of ten years was determined by histological method, but only exceptionally, when more bone diaphysis samples were preserved, this range was shortened by five years, for material from graves 2 and 21 . Urn content is analyzed from graves 1 and 2 and that is the best preserved osteological material, while the osteological material stored in a grave pit is less well preserved. Age at death range can be divided into phase infans - two children up to 14 years (graves 18 and 31), adultus I - four persons of age at death in the 


\begin{tabular}{|c|c|c|c|c|c|}
\hline \multirow{2}{*}{$\begin{array}{l}\text { Broj groba / } \\
\text { Grave number }\end{array}$} & \multirow{2}{*}{$\begin{array}{c}\text { Fragment / } \\
\text { Fragment }\end{array}$} & \multirow{2}{*}{$\begin{array}{l}\text { Broj fragmenata / } \\
\text { Number of fragments }\end{array}$} & \multirow{2}{*}{$\begin{array}{c}\text { Debljina / } \\
\text { Thickness } \\
(\mathrm{mm})\end{array}$} & \multicolumn{2}{|c|}{$\begin{array}{l}\text { Histološka analiza / } \\
\text { Histological analysis }\end{array}$} \\
\hline & & & & $\begin{array}{c}\text { Fragment, broj / } \\
\text { Number of fragments }\end{array}$ & $\begin{array}{c}\text { Broj preparata / } \\
\text { Number of specimen }\end{array}$ \\
\hline G1 & femur & 3 & $4,5-5$ & femur, 2 & 2 \\
\hline G1 & radius & 2 & $3,3-3,5$ & - & - \\
\hline G1 & ossa longa & 5 & $2,3-5,5$ & - & - \\
\hline $\mathrm{G} 2$ & femur & 4 & $5,4-7,5$ & femur, 2 & 2 \\
\hline G3 & femur & 2 & $2,5-7,6$ & femur, 1 & 2 \\
\hline G4 & humerus & 3 & $3-4,5$ & - & - \\
\hline G4 & tibia & 2 & $5,2-7,3$ & tibia, 2 & 3 \\
\hline G9 & femur & 3 & $5-8,3$ & femur, 1 & 1 \\
\hline G12 & ossa longa & 1 & - & ossa longa, 1 & 1 \\
\hline G14 & femur & 2 & $3,8-4,5$ & femur, 2 & 2 \\
\hline G15 & ossa longa & 1 & & ossa longa, 1 & 1 \\
\hline G16 & femur & 1 & & femur, 1 & 2 \\
\hline G20 & humerus & 2 & $2,5-3,1$ & humerus, 1 & 1 \\
\hline $\mathrm{G} 21$ & femur & 2 & $4,5-6,5$ & femur, 1 & 2 \\
\hline G21 & ossa longa & 7 & $4-5,2$ & femur, 1 & 2 \\
\hline G30 & os frontale & 1 & 4,5 & - & - \\
\hline G30 & tibia & 1 & 4,5 & tibia, 1 & 1 \\
\hline G30 & ossa longa & 1 & 6,5 & - & - \\
\hline G34 & femur & 1 & $\begin{array}{c}\text { oštećen / dama- } \\
\text { ged }\end{array}$ & femur, 1 & 2 \\
\hline G37 & femur & 4 & $4,5-7,7$ & femur, 1 & 2 \\
\hline G40 & ossa longa & 1 & - & - & - \\
\hline G45 & os frontale & 1 & 3,5 & - & - \\
\hline G45 & femur & 2 & $\begin{array}{c}\text { oštećen / dama- } \\
\text { ged }\end{array}$ & femur, 1 & 1 \\
\hline GC & femur & 2 & $4,5-7,3$ & femur, 2 & 2 \\
\hline
\end{tabular}

Tab. 2 Histološka metoda analize: fragmenti dijafiza, debljina i broj uzoraka (sjeverozapadna nekropola Siscije) (izradila: Z. Hincak Daris)

Tab. 2 Histological method of analysis: diaphysis fragments, thickness and number of samples (northwest necropolis of Siscia) (made by: Z. Hincak Daris)

i 31), adultus I - četiri osobe doživljene starosti u rasponu 20-30 godina (grobovi 9, 14, 20 i 21), adultus II - četiri osobe doživljene starosti u rasponu $30-40$ godina (grobovi 2, 4 osoba A, 30 i 34), maturus I - dvije osobe u rasponu 40-50 godina (grobovi $1 \mathrm{i}$ C) te pet osoba za koje je moguće utvrditi da pripadaju odraslim osobama (grobovi 12, 15, $16,40,45)(s l .5)$. Dvije osobe, jedna iz groba 3 u fazi je kasni adultus I/rani adultus II starosti 25-35 godina, a druga iz groba 37 je u fazi kasni adultus II/rani maturus I starosti 35-45 godina.

U nekoliko grobova, uz koštane ostatke ljudi, utvrđena je prisutnost spaljenih fragmenata kosti animalnoga podrijetla. Makromorfološkom analizom bilo je teško sa sigurnošću izdvojiti animalne uzorke iz humanoga koštanog materijala grobova. Izuzetak predstavlja proksimalni fragment djelomice spaljene metakarpalne ili metatarzalne kosti maloga glodavca (Rodentia) iz materijala groba 3. Histološkom metodom analize bilo je moguće uzorke taksonomski opredijeliti u razrede ili rodove (tab. 1). Iz urne groba 1 izuzet je fragment dijafize duge kosti. Analizom uzorka utvrđena je pripadnost razredu ptica (Aves), range of 20-30 years (graves 9, 14, 20 and 21), adultus II four persons of age at death in the range of 30-40 years (graves 2, 4 persons A, 30 and 34), maturus I - two persons of age at death in the range of 40-50 years (graves 1 and C) and five persons who can be determined as adults (graves 12, 15, 16, 40, 45) (Fig. 5). Two persons, one from grave 3, is in phase late adultus I/early adultus II age at death in the range of 25-35 years, and the other from grave 37 is in phase late adultus II/early maturus I, age at death in the range of 35-45 years.

Burnt fragments of bones of animal origin were found in several graves, along with human bones. It was difficult to reliably isolate animal samples from human bone material from graves by macromorphological analysis. The exception is the partially burned proximal fragment of the metacarpal or metatarsal bone of a small rodent (Rodentia) from the material of grave 3. By histological method it was possible to taxonomically identify samples into classes or genera (Tab. 1). A fragment of the diaphysis of a long bone was taken from the urn of grave 1, and the analysis of the sample determined that it belonged to the class of birds (Aves), without the possibility of a more precise taxonomic 


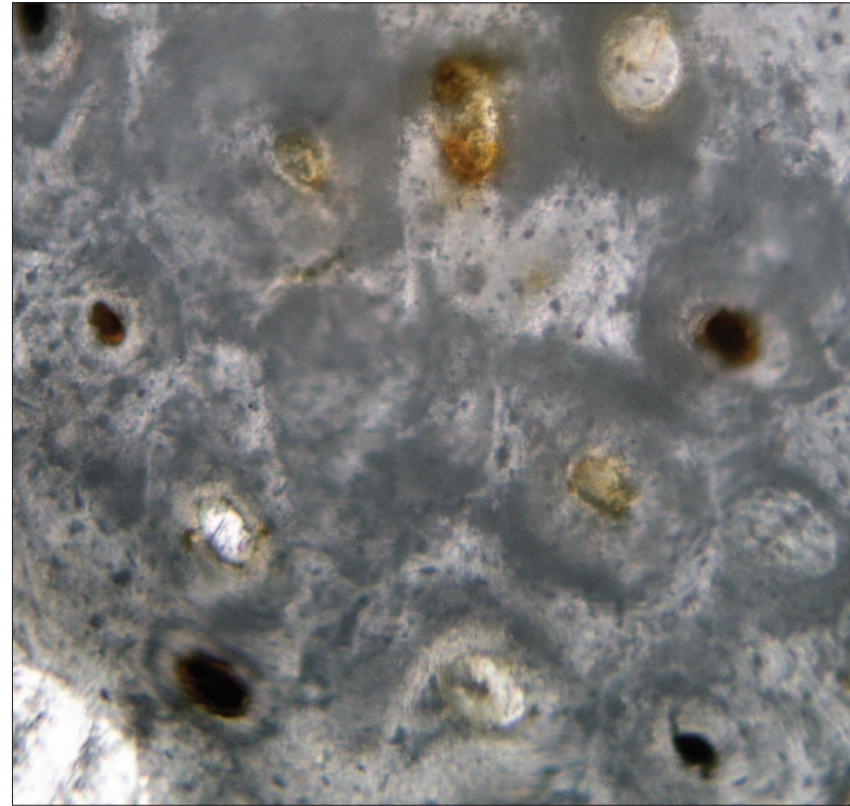

SI. 5 Fotomikrograf prereza dijafize natkoljenične kosti, ženska osoba?, doživljena starost 20-30 godina (adultus I), grob 20, povećanje $20 \times 10$ (sjeverozapadna nekropola Siscije) (snimila: Z. Hincak Daris)

Fig. 5 Photomicrograph of a femoral bone diaphysis section, female?, age at death 20-30 years (adultus I), grave 20, magnification $20 \times 10$ (northwest necropolis of Siscia) (photo by: Z. Hincak Daris)

bez mogućnosti preciznije taksonomske odredbe. Iz urne groba 2 i grobne jame 14 izdvojeni su fragmenti dijafiza dugih kostiju: dva fragmenta natkoljenične ili goljenične kosti (grob 2) te dva fragmenta natkoljenične kosti (grob 14). Analizom četiri preparata utvrđena je pripadnost rodu malih preživača, ovci (Ovis aries, L.) ili kozi (Capra hircus, L.) (sl. 6). Fragment slabo očuvane dijafize natkoljenične kosti životinje izdvojen je iz materijala groba 16. Upravo zbog slabe očuvanosti čvrste tvari (substantia compacta) analizom preparata bilo je moguće utvrditi pripadnost na nivou razreda, velikim preživačima (Ruminantia).

\section{RASPRAVA}

Masa spaljenoga koštanog materijala iz pojedinoga groba prikazana je u grafu 1, uz navedene frakcije. Materijal iz frakcija 1 i 2 te samo izuzetno i iz frakcije 3 predstavlja osnovu makromorfološke i morfometrijske metode analize, dok je za histološku analizu bio pogodan samo izabrani materijal iz frakcije 1. Konačno, masa analiziranoga materijala za pojedini grob još je manja od one prikazane u tab. 1 zbog jake fragmentacije u frakciji 3. Raspon masa materijala iz pojedinih grobova je velik, od 1,31 g (grob 17) do 163,93 g (grob 2). Srednja vrijednost mase iznosi 37,21 g, dok je medijan ( $M_{\mathrm{e}}$ ) nešto niži i iznosi 24,25 g pokazujući da prevladavaju grobovi niske mase. Masa spaljenih ostataka tijela u modernim krematorijima iznosi oko 3,5\% ukupne mase tijela odrasle osobe (Trotter, Hixton 1973). U slučaju spaljenih tijela djece, masa ostataka rijetko prelazi 2,5\%

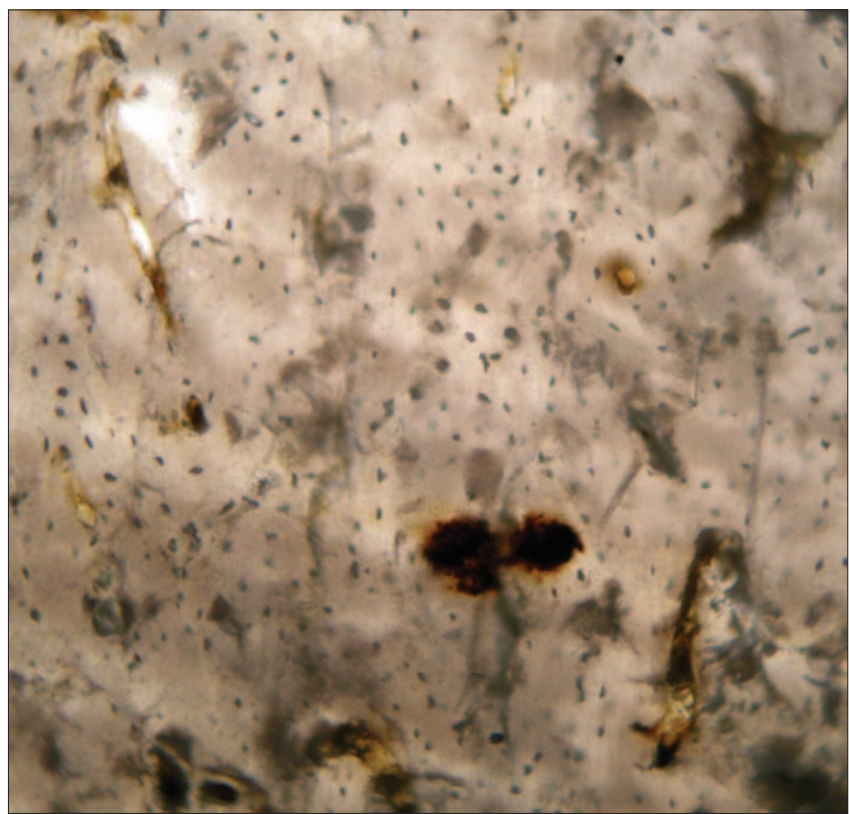

SI. 6 Fotomikrograf prereza dijafize natkoljenične kosti, mali preživači - ovca (Ovis aries, L.), koza (Capra hircus, L.), grob 14, povećanje $20 \times 10$ (sjeverozapadna nekropola Siscije) (snimila: Z. Hincak Daris)

Fig. 6 Photomicrograph of a femoral bone diaphysis section, small ruminants - sheep (Ovis aries, L.), goat (Capra hircus, L.), grave 14, magnification $20 \times 10$ (northwest necropolis of Siscia) (photo by: Z. Hincak Daris)

determination. Fragments of long bone diaphysis were isolated from the urn of grave 2 and grave pit 14: two fragments of the femoral or tibial bone (grave 2) and two fragments of the femoral bone (grave 14). The analysis of four preparations determined the affiliation to the genus of small ruminants, sheep (Ovis aries, L.) or goats (Capra hircus, L.) (Fig. 6). A fragment of the poorly preserved diaphysis of the animal femoral bone was isolated from the material of grave 16. Due to the poor preservation of cortex (substantia compacta), the analysis of the preparation made it possible to determine the affiliation at the class level, large ruminants (Ruminantia).

\section{DISCUSSION}

The mass of burned bone material from each grave is shown in Graph 1, with the stated fractions. Material from fractions 1 and 2, and only exceptionally from fraction 3, is the basis of macromorphological and morphometric analysis, while only selected material from fraction 1 was suitable for histological analysis. Finally, the mass of analyzed material for each grave is even less than shown in Table 1 because of high fragmentation in fraction 3 . The range of masses of material from each grave is large, from $1.31 \mathrm{~g}$ (grave 17) to $163.93 \mathrm{~g}$ (grave 2). The mean value of the mass is $37.21 \mathrm{~g}$, while the median $\left(\mathrm{M}_{\mathrm{e}}\right)$ is slightly lower and is $24.25 \mathrm{~g}$, showing that low-mass graves dominate. The mass of burnt body remains in modern crematoria is about $3.5 \%$ of the total body weight of an adult (Trotter, Hixton 1973). In the case of burnt bodies of children, the 
mase tijela, a u slučaju fetusa tek oko 1,8\% (Warren, Maples 1997). Prevedemo li postotke u grame, masa spaljenih ostataka odrasle osobe nalazi se u rasponu od 870 do 3800 g. Tako bi srednja vrijednost mase analiziranoga materijala odraslih osoba od $37,21 \mathrm{~g}$ u prikazanom rasponu iznosila 4,2-1\% mase spaljenih ostataka osobe.

Kost je građena od vanjskoga, periostalnog dijela koji leži na kortikalnome koštanom tkivu, dok endosteum prekriva unutarnju površinu kosti čija je jezgra sastavljena od čvrstoga i spužvastoga sloja (substantia compacta et substantia spongiosa). Sastav kosti čini organski i anorganski dio te voda. Anorganski dio većinom tvori kalcijev fosfat, preciznije, mineralnu fazu čini slabo kristalinični bioapatit.

Gorenje će različito utjecati na komponente koštanoga tkiva. Iz kristalne rešetke brzo će sublimirati voda i gubit će se karbonat, dok apatit postaje sličan hidroksiapatitu, s većim kristalima i nižom poroznošću. Ukratko, brojne studije pokazale su da pri spaljivanju kostiju na visokim temperaturama, iznad $900{ }^{\circ} \mathrm{C}$, ostaje samo hidroksiapatit što ukazuje da masa spaljenih kostiju u velikoj mjeri pokazuje masu prestale mineralne frakcije kosti. Stoga bi se svi čimbenici koji utječu na mineralnu gustoću kosti morali odraziti i na masu spaljene kosti. Većina analiziranoga humanog materijala gorjela je na temperaturama od $600-900{ }^{\circ} \mathrm{C}$. Na tim temperaturama koštana struktura je očuvana u potpunosti. May ukazuje na neke od čimbenika, poput tjelesnoga indeksa mase osobe, spola i doživljene starosti koji utječu na masu spaljenoga tijela s gotovo $67 \%$, ali i na regionalne razlike između mase tijela i mase spaljenih ostataka (May 2011). Novija istraživanja ističu nužnost uključivanja tafonomskih, kemijskih istraživanja te važnost konteksta (Bocquentin et al. 2020). Tehnika i procesi spaljivanja tijela u modernim krematorijima znatno se razlikuju od spaljivanja pokojnika na lomačama od komada drveta u Indiji koje gore na otvorenoj vatri (Parry 1994; Rambachan 2003). Upravo takav proces bio bi bliži lomačama iz rimskoga vremena o čijim konstrukcijama govori Vitruvije (Vitruv. 2.9.15) kao i procesu koji je doveo do grobova sa spaljenim ostacima osoba u sjeverozapadnoj nekropoli u Sisku. Jedno od objašnjenja za tako malu masu materijala iz pojedinoga groba sjeverozapadne nekropole u Sisciji mogao bi se naći u tafonomskim procesima, tipu tla i pH vrijednosti tla. Posebno se izdvajaju napori koji se ulažu u razvoj histotafonomskih metoda analiza koje prate mikrostrukturnu dijagenezu do koje dolazi u perimortalnoj i postmortalnoj fazi (Bell 2011). Novije studije savjetuju kombinaciju makroskopskih i histoloških metoda analize kako bi se bolje shvatili cjeloviti uvjete gorenja tijela i kostiju (Thompson et al. 2016).

Za većinu uzoraka iz grobova bilo je moguće izdvojiti fragmente dijafiza natkoljenične kosti, potkoljenične kosti i nadlaktične kosti na čijem korteksu se jasno raspoznaje efekt gorenja, polumjesečasta puknuća koja potvrđuju da su kosti u trenutku gorenja bile obložene mekim tkivom, odnosno da je gorjelo tijelo, a ne samo kosti (sl. 2). Takav zaključak je važan jer potvrđuje primarno spaljivanje, unatoč niskoj masi materijala iz pojedinoga groba. Svi analizi- mass of burnt remains rarely exceeds $2.5 \%$ of body weight, and in the case of fetuses only about 1.8\% (Warren, Maples 1997). If the percentages are translated into grams, the mass of burnt remains of an adult ranges from 870 to 3800 $\mathrm{g}$. Thus, the mean value of the mass of the analyzed material of adults of $37.21 \mathrm{~g}$ in the presented range would be $4.2-1 \%$ of the mass of the burned persons remains.

The bone is made up of the outer, periosteal part, which lies on the cortical bone tissue, while the endosteum covers the inner surface of the bone, whose core is composed of a solid and spongy layer (substantia compacta et substantia spongiosa). Bone consists of an organic and an inorganic part and water. The inorganic part consists mainly of calcium phosphate, more precisely, the mineral phase consists of weakly crystalline bioapatite.

Burning will have different effects on bone tissue components. Water will quickly sublimate from the crystal structure and carbonate will be lost, while apatite becomes similar to hydroxyapatite, with larger crystals and lower porosity. In short, numerous studies have shown that when bones are burned at high temperatures, above $900^{\circ} \mathrm{C}$, only hydroxyapatite remains, which indicates that the mass of burned bones largely shows the mass of the remaining bone mineral fraction. Therefore, all factors that affect bone mineral density should be reflected in the mass of burned bone. Most of the analyzed human material burned at temperatures of $600-900^{\circ} \mathrm{C}$. At these temperatures, the bone structure is completely preserved. May points to some of the factors, such as body mass index, gender, and age at death, that affect burned body mass by almost $67 \%$, but also regional differences between body weight and mass of burned remains (May 2011). Recent research highlights the need to include taphonomic, chemical research and the importance of context (Bocquentin et al. 2020). The technique and processes of cremation in modern crematoria are significantly different from the cremation at pyres made of pieces of wood in India, which burn over an open fire (Parry 1994; Rambachan 2003). Exactly such a process would be closer to the pyres from Roman times, whose constructions are mentioned by Vitruvius (Vitruv. 2.9.15), as well as the process that led to the graves with burned human remains in the northwestern necropolis in Sisak. One of the explanations for such a small mass of material from each grave of the northwestern necropolis in Siscia, could be found in taphonomic processes, soil type and soil pH value. Special emphasis is placed on the efforts invested in the development of histotaphonomic methods, which follow the microstructural diagenesis that occurs in the perimortal and postmortem phase (Bell 2011). Recent studies advise a combination of macroscopic and histological methods, to better understand the overall burning conditions of the body and bone (Thompson et al. 2016).

For most of the samples from the graves, it was possible to isolate fragments of the diaphysis of the femoral, tibial and humeral bone and on whose cortex the burning effect is clearly recognizable: crescent-shaped cracks confirming that the bones were lined with soft tissue at the burning process, therefore, the body was burned as well, not just 
rani uzorci bili su u potpunosti spaljeni, a pronađeni su u jami s debljim slojem ugljena, izuzev grobova 1 i 2 gdje je materijal bio pohranjen u urnu. Analiza boja spaljenih kostiju ukazuje na malu razliku materijala iz urni i onih koji su bili položeni u zemlju. Boja najsvjetlijega materijala iz urni pokazuje bijelo do bijelo ružičastu boju koja nije utvrđena na materijalu iz ostalih grobova. Boja materijala koji je gorio na najvišim temperaturama iz ostalih grobova nalazi se u rasponu od bijelo sive do bijelo žućkaste boje, čak i za uzorke koji su u potpunosti kalcinirani (tab. 1). Nedostatak bijele boje $s$ ružičastom nijansom kod materijala koji gori na najvišim stupnjevima temperature Symes objašnjava obiljem ugljika u gornjem sloju tla, odnosno u grobnoj jami te kašnjenjem u karbonizaciji kosti, čak i na vrlo visokim temperaturama od 900 do $1000^{\circ} \mathrm{C}$ (Symes et al. 2015). Takav opis odgovarao bi spaljivanju u jami, no takav zaključak u slučaju sjeverozapadne nekropole nije moguće donijeti sa sigurnošću. Problem predstavlja boja materijala koja je gorjela na nižim temperaturama, a opisana je u tab. 1. U slučaju klasičnoga spaljivanja u jami morali bi postojati jasni tragovi zakašnjele karbonizacije na svom koštanom materijalu koji je položen u zemlju, što u slučaju nekropole nije utvrđeno.

Arheološka istraživanja daju podatak da su se grobne jame punile materijalom zaostalim nakon gorenja lomače. Najbolje su vidljive u grobnim jamama broj 31 i 45 koje su duboko zapunjene garom, pepelom i ostatkom s lomače. One, uz grob 30, jedine imaju oblik prave grobne rake, tako da nije potpuno jasno jesu li kod groba 30 zapečene stranice posljedica toga što su još vrući gar ubacili u raku. Možda je iznad svih raka bila postavljena lomača, no to se ne može dokazati. Ako je još vrući gar ubačen u raku tada lomača nije mogla biti daleko od mjesta pokopa pokojnika. Nije jasno zašto je u tom slučaju masa koštanoga materijala tako niska te bi se za pojedine cjelovito očuvane dublje iskopane grobove (10 i 17) moglo reći da su koštani fragmenti prisutni u tragovima. Za veliki broj grobova količina očuvanoga sadržaja je posljedica velikih oštećenja. Gorenje će različito utjecati na komponente koštanoga tkiva. Ostaje otvoreno pitanje jesu li tijela gorjela na lomači izvan ili u samoj grobnoj jami. Teoretski, prema izgledu rake sa zapečenim stranicama to bi bilo moguće u slučaju groba 30 , ali $i$ to je upitno. Međutim, na koštanome materijalu iz Siscije nema tragova zakašnjele karbonizacije uslijed nedostatka kisika. Vjerojatno su tijela spaljivana negdje u blizini, ostaci su prilagani u urne ili u obične jame. Ostaje otvoreno pitanje dubine grobnih jama i dostupnosti kisika. Teško je govoriti je li moguće da su kosti gorjele na lomači koja je bila u jami kada je teroretski dubina sezala od $20-50 \mathrm{~cm}$, dok pravo stanje ukazuje na dubinu u rasponu $50-70 \mathrm{~cm}$.

Makromorfološka analiza provedena je na materijalu iz svih navedenih grobova (tab. 1). Materijal iz groba 4 sadržavao je ostatke dvije odrasle osobe. Pojedine strukture koštanih elemenata pokazivale su muške značajke, prije svega robusnost hvatišta mišića i općenito robusnost elemenata. Malobrojni ostaci druge, ženske osobe su iznimno gracilni, što je posebno uočljivo na hrapavosti proksimalne the bones (Fig. 2). Such a conclusion is important because it confirms the primary cremation, despite the low mass of material from a particular grave. All analyzed samples were completely burned and found in a pit with a thicker layer of charcoal, except for graves 1 and 2, where the material was stored in an urn. The color analysis of the burned bones indicates a small difference between the materials from the urn and those that were laid in the ground. The color of the lightest material from the urn shows a white to white-pink color, which isn't found on the material from other graves. The color of the material burned at the highest temperatures from other graves ranged from whitegray to white-yellowish, even for samples that were fully calcined (Tab. 1). Symes explains the lack of white color with a pink tinge in the material that burns at the highest temperature levels by the abundance of carbon in the upper layer of the soil, i.e. in the grave pit and the delay in bone carbonization, even at very high temperatures from 900 to $1000^{\circ} \mathrm{C}$ (Symes et al. 2015). Such a description would correspond to burning in a pit, but such a conclusion in the case of the northwestern necropolis can't be reached with certainty. The problem is the color of the material that burned at lower temperatures and is described in Table 1. In the case of classical incineration in the pit, there should be clear traces of delayed carbonization on all bone material, which was laid in the ground, which was not found in the necropolis.

Archaeological research provides information that the grave pits were filled with material left over from the burning of the pyre. They are best seen in grave pits 31 and 45 which are deeply filled with charcoal, ashes and the remains from the pyre. They, along with grave 30 , are the only ones to have the shape of a real grave pit, so it is not entirely clear whether the burned sides at grave 30 are a consequence of the fact that still hot embers were put in the grave pit. A pyre may have been placed above all the grave pits, but this can't be proven. If a still hot ember was inserted into the grave pit, then the pyre couldn't be far from the burial place. It is not clear why in this case the mass of bone material is so low, and for some completely preserved deeper excavated graves (10 and 17) it could be said that bone fragments are present in the traces. For many graves, the amount of preserved content is the result of extensive damage. Burning will affect bone tissue components differently. The question remains, were the bodies burned at the pyre outside or in the grave pit. Theoretically, according to the appearance of the grave pit with burned sides, that would be possible in the case of grave 30 , but even that is questionable. However, there are no traces of delayed carbonization due to lack of oxygen on the bone material from Siscia. Probably the bodies were burnt somewhere nearby, and the remains were placed in urns or in ordinary pits. The question of the depth of grave pits and the availability of oxygen remains open. It is difficult to say whether the bones burned on a pyre that was in the pit, when theoretically depth of the pit reached 20-50 $\mathrm{cm}$, while the true condition indicates a depth in the range of $50-70 \mathrm{~cm}$. 
dijafize lakatne kosti koja, uz ostale ostatke, potvrđuje kako je riječ o odrasloj osobi. Ukoliko nije došlo do probijanja slojeva i miješanja koštanoga materijala iz ranijih slojeva pri terenskome istraživanju ili kontaminacije na drugi način, u samome procesu spaljivanja ili nakon njega, ovaj grob je opredijeljen kao dvojni grob. Materijal iz groba 31 makromorfološkom analizom je opredijeljen kao dječji grob zbog prepoznatljivih anatomskih elemenata ili njihovih dijelova. Za većinu materijala iz grobova ovom metodom mogla se odrediti samo pripadnost odraslim osobama, s izuzetkom grobova vrlo niske mase poput groba 17 za kojeg je utvrđeno humano podrijetlo materijala (tab. 1). Za materijal iz grobova 12, 18, 40 nije bilo moguće utvrditi jesu li humanoga ili animalnoga podrijetla. Fragmenti zuba stalne denticije nisu česti, utvrđeni su za samo šest grobova (grobovi 2, 3, 4, 14, 20, C). Na žalost, zbog visoke fragmentacije nije bilo moguće podrobnije analizirati okluzalne plohe kruna za odredbu doživljene starosti niti korijene zuba.

U tab. 1 naveden je spol za osobe čiji se materijal nalazi u pojedinim grobovima, no zbog uporabe sekundarne morfometrijske metode pouzdanost rezultata je upitna. Odredba spola nije bila primarni cilj ovoga istraživanja. Zbog male mase materijala i velike fragmentiranosti, na humanome materijalu provedena je sekundarna metoda odredbe spola, odnosno morfometrijska analiza. Treba naglasiti kako je mjerenjem debljina fragmenata dijafiza nadlaktične, natkoljenične i goljenične kosti bilo moguće tek pretpostaviti spol osoba iz nekih grobova. Rezultati u tab. 1 pokazuju da je moguće pretpostaviti spol za jedanaest osoba - pet žena (grobovi 1, 3, 4B, 14, 20) i šest muškaraca (grobovi 2, 4A, 9, 30, 37, C).

Patološke promjene zabilježene su za samo jedan uzorak muške osobe iz groba 37, a kreću se u rasponu od 35 do 45 godina. Riječ je o fragmentu dijafize goljenice $s$ izraženim aktivnim periostitisom duljine $14,2 \mathrm{~mm}$ (sl. 4). Aktivni periostitis na sl. 4 ima naznačene rubove koji se, osim visinom i sivkastom bojom, odvajaju od korteksa koji leži ispod. Opisane promjene odnose se na grubo vlaknastu kost koja se stvara i oblaže vanjsku koru poput slojeva svijetlo sive mreže. Periostitis može nastati uslijed aktivnosti infekcije, posljedice izravne traume ili skorbuta (Mann, Hunt 2005). Aktivni periostitis često je prisutan na dijafizama goljenica odraslih osoba, posebno muškaraca, iz različitih arheoloških razdoblja. Razlog je vjerojatno upala pokosnice uslijed izravnih trauma poput padova, ugriza životinja, ozljeda prilikom rukovanja alatima ili traume uzrokovane oružjem.

Histološka metoda analize zaokružila je rezultate ranije dobivene makromorfološkom analizom, uz točniju odredbu doživljene starosti u rasponu od pet (grobovi $2,21 \mathrm{i}$ C) ili deset godina (grobovi 1, 2, 3, 4A, 9, 14, 20, 30, 34 i 37) zahvaljujući dobro očuvanoj čvrstoj tvari kosti (substantia compacta), uz pomoć akrilnih smola za učvršćivanje (tab. 1-2). Fragmenti dugih kostiju djece iz grobova 18 i 31 bili su dovoljno očuvani za analizu, no njome je moguće utvrditi kako je riječ o dječjim kostima uz široki raspon doživljene
Macromorphological analysis was performed on material from all listed graves (Tab. 1). The material from grave 4 contained the remains of two adults. The individual structures of the bone elements showed masculine characteristics, primarily the robustness of the muscle attachments and the robustness of the elements in general. The few remains of the second, female individual are extremely graceful, which is especially noticeable on the tuberosity of the proximal diaphysis of the ulnar bone, which, along with other remains, confirms that it is an adult. If there was no penetration of layers and mixing of bone material from earlier layers during field research, or contamination in any other way, in the process of burning or after it, this grave is designated as a double grave. The material from grave 31 was determined as a child's grave by macromorphological analysis, due to the recognizable anatomical elements or their parts. For most materials from graves, this method could only determine the affiliation of adults, except for graves with very low mass, such as grave 17 , for which the human origin of the material was determined (Tab. 1). For the material from graves $12,18,40$ it was not possible to determine whether they were of human or animal origin. Fragments of permanent dentition teeth are not common, they were confirmed for only six graves (graves 2, 3, 4, 14, 20, C). Unfortunately, due to the high fragmentation, it was not possible to analyze in detail the occlusal surfaces of the crowns to determine the age at death or the roots of the teeth.

Tab. 1 shows gender for persons whose material is found in individual graves, but due to the use of the secondary morphometric method, the reliability of the results is questionable. Determination of gender was not the primary goal of this study. Due to the small mass of the material and the high fragmentation, a secondary method of gender determination, morphometric analysis, was performed on the human material. It should be emphasized that by measuring the thickness of the diaphysis fragments of the humeral, femoral and tibial bone, it was only possible to assume the gender of persons from some graves. The results in Table 1 show that it is possible to assume gender for eleven persons, five women (graves 1, 3 , $4 B, 14,20$ ) and six men (graves 2, 4A, 9, 30, 37, C).

Pathological changes were recorded for only one sample of a male, ranging from 35 to 45 years from grave 37. It is a fragment of the diaphysis of the tibial bone with pronounced active periostitis, $14.2 \mathrm{~mm}$ long (Fig. 4). The active periostitis in Fig. 4 has marked edges, which, apart from their height and grayish color, separate from the cortex that lies below. Described changes relate to the woven bone, which forms and coats the outer crust like layers of light gray mesh. Periostitis can occur due to infection, trauma or scurvy (Mann, Hunt 2005). Active periostitis is often present on the diaphysis of the tibial bone of adults, especially men, from different archaeological periods. The reason is probably inflammation of periosteum due to trauma such as falls, animal bites, injuries when handling tools or trauma caused by weapons.

Histological analysis rounded off the results previously obtained by macromorphological analysis, with a more 
starosti do 14 godina (infans). Ova metoda analize pokazuje vrlo velika odstupanja za dječje uzorke i upotrebljava se isključivo za uzorke osoba starijih od dvadeset godina. Kod uzoraka odraslih osoba prevladava gusto pregrađivanje osteona koje je moguće kronološki pratiti (sl. 5), no kod uzoraka uzetih iz dijafiza djece prevladavaju procesi njihova rasta i oblikovanja. Tako je gustoća primarnih osteona u negativnome odnosu prema rastu godina starosti te pada od dječjih prema kasnim adolescentskim godinama, dok je broj sekundarnih osteona u odnosu na jedinicu površine najveći u adolescentskim godinama, a uopće se ne uočavaju u uzorku kostiju djece prije druge godine života. Dok je makroskopskom metodom materijal iz groba 31 jasno označen kao dječji, za skroman materijal iz groba 18 tek se histološkom metodom utvrdilo da je riječ o dječjem grobu. Problem krtih uzoraka bilo je moguće riješiti uporabom smola, no poseban problem predstavljali su fragmenti jače oštećenih dijafiza iz grobova 12, 15, 16, 40 i 45 . Kako takvi uzorci nisu mogli dati potpuni transverzalni presjek čvrste tvari, histološka analiza je mogla samo potvrditi humano podrijetlo uzorka te da su uzorci pripadali odraslim osobama.

Učinjeno je dvadeset devet histoloških preparata iz dvadeset dva uzorka dijafiza za sedamnaest grobova (tab. 1-2). Dobra očuvanost čvrste tvari pokazala se ključnom za utvrđivanje prihvatljivih raspona doživljene starosti. Makromorfološkom analizom iz materijala humana podrijetla izdvojeni su uzorci koji bi mogli pripadati životinjama (grobovi 1, 2, 14, 16). Pretežno su to fragmenti dijafiza dugih kostiju. Fragment distalnoga dijela zastoplja ili zapešća malog glodavca (Rodentia) iz groba 3 vjerojatno predstavlja slučajni nalaz koji je više povezan s drvenim materijalom za lomaču nego s grobnim prilogom. Histološkom analizom utvrđeni su koštani fragmenti životinja, ptice, malih preživača - ovce ili koze i preživača. Općenito, red viših sisavaca, parnoprstaši (Artiodactyla), kojima pripadaju preživači pokazuju uzorak čvrste tvari kostiju sličan ljudskome s Haversovim sustavima, no opseg, raspored i veličina struktura se razlikuju (sl. 6). Uzorak koštane mikrostrukture malih preživača i preživača općenito (grobovi 2, 14 i 16) obuhvaća pleksiformnu kost u vanjskim slojevima čvrste tvari i gustih Haversovih sustava u srednjim i endostealnim slojevima (sl. 6). Uzorak duge kosti ptice iz groba $1 \mathrm{u}$ potpunosti se razlikuje od ljudskoga uzorka, a pokazuje fibrolamelarnu kost okruženu periferno i endostealno uskim slojem lamelarne kosti.

Izbor histološke metode analize na fragmentima dijafiza dugih kostiju bio je logičan izbor, jer je analiziran spaljeni koštani materijal i najbolje su očuvani ostaci dijafiza dugih kostiju. Teoretski, preciznije raspone doživljene starosti mogla bi pružiti histološka metoda na tijelima rebara (Stout, Pane 1992; Robling, Stout 2000; Cho et al. 2002; Chan et al. 2007; Streeter 2010), no upravo rebra u spaljenome materijalu pokazuju visoku krhkost i oštećenost tankoga sloja čvrste tvari.

Jedini rimskodobni lokalitet u Hrvatskoj na čijem je materijalu iz grobova provedena histološka metoda ana- accurate determination of age at death in the range of five (graves 2, 21 and C) or ten years (graves 1, 2, 3, 4A, 9, $14,20,30,34$ and 37), thanks to the well-preserved cortex (substantia compacta), with the help of acrylic fixing resins (Tabs. 1-2). Fragments of children's long bones from graves 18 and 31 were sufficiently preserved for analysis, but it is possible to determine that these are children's bones with a wide range of age at death up to 14 years (infans). This method of analysis shows very large deviations for children's samples and is used exclusively for samples of persons older than twenty years. In adult samples, osteons remodeling predominates, which can be traced chronologically (Fig. 5), but in samples taken from children's diaphysis, the processes of their growth and shaping predominate. Thus, the density of primary osteons is in negative relation to the growth of age and decreases from childhood to late adolescence, while the number of secondary osteons per unit area is highest in adolescence, and not observed in the bone sample of children younger than two years. While the material from grave 31 was clearly marked as child's by the macroscopic method, only by histological method was it determined that grave number 18 was child's, since modest material was found. The problem of brittle samples could be solved by using resins, but a special problem was represented by fragments of severely damaged diaphysis from graves $12,15,16,40$ and 45 . As such samples couldn't give a complete transverse cross section of cortex, histological analysis could only confirm human origin of the sample and that they are adults.

Twenty-nine histological preparations were made from twenty-two diaphysis samples for seventeen graves (Tabs. 1-2). Good preservation of the cortex proved to be crucial in determining acceptable ranges of age at death. Using macromorphological analysis, samples that could belong to animals were extracted from materials of human origin (graves 1, 2, 14, 16). These are mostly fragments of long bone diaphysis. A fragment of the distal part of the fist or foot phalanx of a small rodent (Rodentia) from grave 3 probably represents a random find, which is more associated with the wooden material for the pyre than with the grave offering. Histological analysis determined bone fragments of animals, birds, small ruminants - sheep or goats and ruminants. In general, the order of higher mammals, the Artiodactyla, to which ruminants belong, show a human-like cortex bone, with Haversian systems, but the extent, arrangement, and size of the structures differ (Fig. 6). The bone microstructure pattern of small ruminants and ruminants in general (graves 2, 14 and 16) comprises plexiform bone in the outer layers of cortex and dense Haversian systems in the middle and endosteal layers (Fig. 6). The long bone sample of the bird from grave 1 is completely different from the human sample, showing fibrolamelar bone surrounded by a peripheral and endosteal narrow layer of lamellar bone.

The choice of the histological analysis on fragments of long bone diaphysis was a logical choice, because the burnt bone material was analyzed, and the remains of long bone diaphysis were best preserved. Theoretically, more precise ranges of the age at death could be provided by 
lize spaljenih ostataka jest Šepkovčica pokraj Velike Gorice u Turopolju. Analiza je obuhvatila osamnaest grobova s urnama od kojih je većina datirana u raspon od druge polovice 1. do 2. st., a manjina grobova je pripadala 4. st. Razlog zbog kojega je izabrana histološka metoda jest slaba očuvanost i mala brojnost koštanoga materijala u urnama (Hincak et al. 2007). Usporedi li se boja spaljenih uzoraka kosti, odmah se uočava razlika, iako su kosti s oba nalazišta potpuno spaljene. Nijanse bijele boje u Šepkovčici dosežu do ružičaste nijanse, dok se takvi uzorci u nekropoli iz Siscije ne nalaze. Možda razlog ne treba tražiti isključivo u procesu spaljivanja tijela, lomači na zraku uz potpuni pristup kisika ili u jami. Postoji razlika u očuvanosti osteoloških elemenata i uvjeta koji vladaju u zaštićenome prostoru urne ili u tlu, direktnim zasipavanjem spaljenih ostataka u jamu i pokrivanja zemljom kada postoji direktan utjecaj sedimenta na spaljene kosti, posebno kroz dugo vremensko razdoblje. Materijal iz Šepkovčice pokazao je veću prisutnost potpuno spaljenih životinjskih kostiju pomiješanih s humanim materijalom. Zanimljiv je podatak da su na oba lokaliteta utvrđeni spaljeni ostaci malih preživača - ovce ili koze, ptice i velikih preživača, što može biti pokazatelj uobičajenoga sadržaja grobnih priloga na lomači toga vremena i vjerojatno užega geografskoga prostora. Štoviše, najveći postotak životinjskih ostataka kao grobnoga priloga nalazišta Šepkovčica zauzimaju koštani ostaci malih preživača, a tek nakon toga goveda, svinja, jelena ili kokoši. Zbog nešto bolje očuvanih humanih koštanih uzoraka, za nalaze iz Šepkovčice bilo je moguće histološkom analizom utvrditi kraći raspon doživljene starosti od pet godina. Također, nalazi iz Šepkovčice i nekropole iz Siscije obuhvatili su odrasle osobe oba spola i koštane ostatke djece.

\section{ZAKLJUČAK}

Histološka metoda analize spaljenih kosti u arheološkome kontekstu može pružiti preciznije podatke o doživljenoj starosti osobe koji nadilaze makromorfološku antropološku analizu. Mogućnost mikroskopskoga istraživanja može otkriti detalje o tafonomskim procesima koji imaju važan utjecaj na stanje koštanoga materijala. Makroskopskom i histološkom analizom obuhvaćen je dvadeset jedan paljevinski grob iz sjeverozapadne nekropole u Sisku. Prema pronađenim arheološkim predmetima i AMS metodom analize radioaktivnoga izotopa ${ }^{14} \mathrm{C}$ nekropola je datirana u raspon od 1. do 3. st. Grobovi 1 i 2 sadržavali su osteološki materijal pohranjen u urne, dok su grobovi 31 i 45, duboko napunjeni ostatkom iz lomače, jedini imali oblik prave grobne rake, uz grob 30 čije su stranice rake bile zapečene. Ostali grobovi imaju dobro definirane grobne rake $s$ rasutim materijalom $s$ lomače. Za sve grobove kojima je sadržaj lomače pomiješan sa zemljom nije nužno da je materijal s lomače nasut u jame, već postoji mogućnost da se lomača postavljala direktno iznad ili je slagana u samu jamu. Teoretski, lomača koja se nalazila i gorjela u jami, prije svega, moguća je u slučaju groba 30 sa zapečenim stranicama jame. the histological method on the bodies of the ribs (Stout, Pane 1992; Robling, Stout 2000; Cho et al. 2002; Chan et al. 2007; Streeter 2010), but the ribs in the burnt material show high fragility and damage of a thin layer of cortex.

The only Roman-era site in Croatia, on whose material from the graves the histological method of analysis of the burnt remains was carried out, is Šepkovčica, near Velika Gorica in Turopolje. The analysis included eighteen graves with urns, most of which date from the second half of the $1^{\text {st }}$ to the $2^{\text {nd }}$ century, and a smaller number of graves belong to the $4^{\text {th }}$ century. The reason why the histological method was chosen is the poor preservation and small number of bone material in the urns (Hincak et al. 2007). If the color of the burned bone samples is compared, the difference is immediately noticeable, although the bones from both sites are completely burned. Shades of white in Šepkovčica reach the shade of pink, while such samples aren't found in the necropolis from Siscia. Perhaps the reason is not just in the process of burning the body, pyre in the air with full access to oxygen, or in a pit. There is a difference in the preservation of osteological elements and conditions prevailing in the protected space of the urn or in the ground, by direct burial of burnt remains in the pit and covering with earth, when there is a direct impact of sediment on burned bones, especially over a long period. Material from Šepkovčica showed a higher presence of completely burned animal bones mixed with human material. It is interesting to note that on both sites, burned remains of small ruminants - sheep or goats, birds and large ruminants - were found, which may be an indicator of the usual content of grave goods on the pyre of that time and probably geographical area. Moreover, the largest percentage of animal remains as a grave offering of the Šepkovcica site is occupied by the bone remains of small ruminants, and only after that by cattle, pigs, deer or chickens. Due to slightly better-preserved human bone samples, for the findings from Šepkovčica it was possible by histological analysis to determine a shorter range of age at death than five years. Also, the findings from Šepkovčica and the necropolis from Siscia included adults of both gender and the bone remains of children.

\section{CONCLUSION}

The histological method of burnt bone analysis in an archaeological context can provide more precise data on a person's age at death, which goes beyond macromorphological anthropological analysis. In addition, the possibility of microscopic examination can reveal details about taphonomic processes, which have a significant impact on the condition of bone material. The macroscopic and histological analysis included 21 cremation graves from the northwestern necropolis in Sisak. According to the archaeological objects found and the AMS method of analysis of the radioactive isotope ${ }^{14} \mathrm{C}$, the necropolis is dated from the $1^{\text {st }}$ to the $3^{\text {rd }}$ century. Graves 1 and 2 contained osteological material stored in urns, while graves 31 and 45 , deeply filled with the remains of the pyre, were the only ones that have the shape of a real grave pit, besides grave 30 , whose sides of the pit were burned. Other graves have 
Analizirani osteološki materijal bio je slabo očuvan, srednje vrijednosti mase $37,21 \mathrm{~g}$, s medijanom $\left(M_{e}\right)$ koji iznosi $24,25 \mathrm{~g}$ i pokazuje da su grobovi iz nekropole pretežno niske mase. Sav materijal je spaljen. Prema boji ostataka temperature gorenja nalazile su se u rasponu od $600-900{ }^{\circ} \mathrm{C}$, a viša temperatura bi promijenila građu fragmenata kostiju. Boja materijala je u širokome rasponu od tamnije sive ili smeđe do svijetlo sive, bijelo žućkaste do bijele. Materijal je visoko fragmentiran i pokazuje deformacije kosti karakteristične za djelovanje visoke temperature. Stvaranje polumjesečastih puknuća na dijafizama nadlaktične i natkoljenične kosti tijekom gorenja potvrđuje se da su gorjela tijela, a ne samo kosti. Rezultati makromorfoloških i histoloških metoda analize pokazali su da je u nekropoli pokopano dvoje djece doživljenoga raspona starosti u fazi infans - do 14 godina (grobovi 18 i 31), četiri osobe doživljene starosti u rasponu 20-30 godina faze adultus I (grobovi 9, 14, 20 i 21), četiri osobe doživljene starosti u rasponu 30-40 godina faze adultus II (grobovi 2, 4A, 30 i 34), dvije osobe u rasponu 40-50 godina faze maturus I (grobovi $1 \mathrm{i}$ C) te pet osoba za koje je bilo moguće utvrditi da pripadaju odraslim osobama (grobovi 12, 15, 16, $40,45)$. Dvije osobe, jedna iz groba 3 u fazi je kasni adultus I/rani adultus II doživljene starosti 25-35 godina, a druga iz groba 37 je u fazi kasni adultus II/rani maturus I starosti 35-45 godina. Grobovi su bili individualni, osim u slučaju groba 4 koji je dvojan sa spaljenim ostacima odrasle muške i ženske osobe. Za grobove s najnižom masom materijala bilo je moguće utvrditi humano podrijetlo (grob 17), dok je za materijal iz groba 10 ostalo otvoreno pitanje je li riječ o materijalu animalnoga ili humanoga podrijetla. Spol je određen za jedanaest osoba, pet žena i šest muškaraca, prema sekundarnoj morfometrijskoj metodi, mjerenju debljine fragmenata dijafiza pojedinih dugih kostiju i nije od važnosti za ovaj rad. Patološke promjene u smislu aktivnog periostitisa utvrđene su na fragmentu dijafize goljenične kosti, najvjerojatnije muške osobe doživljene starosti od 35-45 godina. U nekoliko grobnih jama, uz koštane ostatke ljudi, histološkom je metodom utvrđena prisutnost spaljenih fragmenata kostiju animalnoga podrijetla: uzorak kosti ptice (Aves) u grobu 1, uzorci kostiju malih preživača, ovce (Ovis aries, L.) ili koze (Capra hircus, L.) u grobovima 2 i 14 te uzorak kostiju velikoga preživača (Ruminaintia) u grobu 16. Fragment spaljenoga članka prsta zapešća ili zastoplja maloga glodavca (Rodentia) utvrđen je u grobu 3.

Histološka metoda je destruktivna, bez obzira koliko se malen uzorak izuzima iz kosti. Stoga je prije izbora metode potrebno dobro procijeniti je li ovakvo namjerno oštećivanje kosti s arheoloških nalazišta vrijedno podataka koje nam analiza može pružiti. U slučaju malobrojnoga i slabo očuvanoga materijala, poput analiziranoga, ova je metoda jedina koja uopće može dati značajne antropološke podatke. Primjer analize spaljenoga materijala iz grobova sjeverozapadne nekropole u Sisciji pokazuje kako se i na vrlo slabo očuvanom materijalu kombinacijom makroskopske i mikroskopske tehnike analize mogu dobiti vrijedni podaci. Histološka metoda analize razvija se snažno posljednjih a well-defined pit with bulk material from the pyre. For all graves with the contents of the pyre mixed with earth, it is not necessary that the material from the pyre is poured into the pits, but there is a possibility that the pyre was placed directly above or stacked in the pit. Theoretically, a pyre that was located and burned in the pit is primarily possible in the case of grave 30 , with the burned sides of the pit.

The analysed osteological material was poorly preserved, with a mean weight of $37.21 \mathrm{~g}$, with a median $\left(\mathrm{M}_{\mathrm{e}}\right)$ of $24.25 \mathrm{~g}$ which indicates that the graves were predominantly of low mass. All material was burned. According to the colour of the remains, the burning temperatures were in range $600-900^{\circ} \mathrm{C}$. A higher temperature would change the bone structure. The colour of the material ranges widely from darker gray or brown to light gray, white yellowish to white. The material is highly fragmented and shows bone deformations characteristical for a high- temperature exposure. The formation of a crescent-shaped fissures on the diaphyses of the humeral and femoral bone during burning confirmed that the bodies were burning, not just bones. The results of macromorphological and histological mathods of analysis showed that in the necropolis were buried two children at age at death in infans phase, up to 14 years (graves 18 and 31), four persons in age range 20-30 years of the adultus I phase (graves 9, 14, 20 and 21), four persons in age range 30-40 years of the adultus II phase (graves 2, 4A, 30 and 34), two persons in age range 40-50 years of the maturus I phase (graves 1 and C) and five persons determinated as adults (graves 12, 15, $16,40,45)$. Person from the grave 3 is in late adultus l/early adultus II phase, aged $25-35$ years, and another one, from the grave 37 is in phase late adultus II/early maturus I, aged 35-45 years. The graves were individual; an exception is grave 4, which is double, with the burned remains of male and female person. For graves with the lowest mass of material, it was possible to determine the human origin (grave 17), while for the material from grave 10 the question remained whether it was material of animal or human origin. Gender was determined for eleven persons, five woman and six men, according to the secondary morphometrical method, measuring the thickness of the fragments of the diaphysis of individual long bones and it is not relevant to this work. Pathological changes in terms of active periostitis were found on a fragment of the tibial bone diaphysis, most likely a male person aged $35-45$ years. In several grave pits, in addition to human bone remains, the presence of burned bone fragments of animal origin was determined by the histological method: a sample of bird bones (Aves) in grave 1, bone samples of small ruminants, sheep (Ovis aries, L.) or goats (Capra hircus, L.) in graves 2 and 14 , and a bone sample of a large ruminant (Ruminaintia) in grave 16. In grave 3 , a fragment of burned phalanx of fist or foot of a small rodent (Rodentia) was found.

The histological method is destructive, no matter how small a sample is taken from the bone. Therefore, before choosing a method, it is necessary to carefully assess whether such intentional bone damage from archaeological sites is worth the data that the analysis can provide. 
tridesetak godina, uglavnom zahvaljujući potrebi u okviru forenzike, no ne treba zapostaviti i važnost primjene u paleopatologiji i bioarheologiji.

\section{ZAHVALE}

Autori zahvaljuju kolegama iz Gradskoga muzeja Sisak za susretljivost i pomoć. Istraživanje je provedeno u okviru projekta "Lobor - ranosrednjovjekovno središte moći" (LearlyCoP IP-2016-06-6622).
In the case of a small ammount and poorly preserved material, such as the one alnalyzed, this method is the only one that can give significant anthropological data at all. An example of the burnt bones analysis from the graves of the northwestern necropolis in Siscia shows that even on very poorly preserved material, a combination of macroscopical and microscopical methods can give more precise data. The histological method of analysis has been developing strongly in the last thirty years, mainly due to forensics' needs, but the importance of its application in paleopathology and bioarchaeology should not be neglected.

\section{ACKNOWLEDGMENTS}

The authors would like to thank collegues from Sisak City Museum for kindness and help. The research was conducted within the project "Lobor - Early Medieval Center of Power" (LearlyCoP IP-2016-06-6622). 


\section{LITERATURA / BIBLIOGRAPHY}

Barnes, I., Young, J., Dobney, K. 2000, DNA-based identification of goose species from two archaeological sites in Lincolnshire, Journal of Archaeological Science, Vol. 27(2), 91-100. https://doi.org/10.1006/ jasc.1999.0440

Blau, S., Ubelaker, D. H. 2016, Handbook of Forensic Anthropology and Archaeology (World Archaeological Congress Research), Routledge, New York.

Bell, L. S. 2011, Histotaphonomy, in: Bone histology. An Anthropological Perspective, Crowder C., Stout S. (eds.), CRC Press, Boca Raton, 241-252.

Bocquentin, F., Anton, M., Berna, F., Rosen, A., Khalaily, H., Greenberg, H., Hart, T. C., Lernau, O., Kolska Horwitz, L. 2020, Emergence of corpse cremation during the Pre-Pottery Neolithic of the Southern Levant: A multidisciplinary study of a pyre-pit burial, PlOS ONE, Vol. 15(8), 1-44. https://doi.org/10.1371/journal.pone.0235386

Buikstra, J. E., Ubelaker, D. H. 1994, Standards for Data Collectionfrom Human Skeletal Remains, Arkansas Archaeological Survey Research Series No. 44, Arkansas Archaeological Survey Research, Fayetteville. https://doi.org/10.1002/ajhb.1310070519

Chan, A., Crowder, C., Rogers, T. 2007, Variation in cortical bone histology within the human femur and its impact on estimating age at death, American Journal of Physical Anthropolology, Vol. 132(1), 80-88. https://doi.org/10.1002/ajpa.20465

Cho, H., Stout, S. D., Madsen, R. W., Streeter, M. A. 2002, Population-specific histological age estimating method: a model for known African-American and European American skeletal remains, Journal of Forensic Sciences, Vol. 47(1), 12-18.

Cerezo-Román, J. I., Deforce, K., Henrotay, D., Van Neer, W. 2017, From life to death. Dynamics of personhood in Gallo-Roman funerary customs, Luxemburg Province, Belgium, in: Cremation and the archaeology of death, Cerezo-Román J. I., Wessman A., Williams H. (eds.), Oxford University Press, Oxford, 148-176. doi: 10.1093/ oso/9780198798118.003.0017

De Haan, J. D. 2015, Fire and bodies, in: The analysis of burned human remains, Schmidt C. W, Symes S. (eds.), $2^{\text {nd }}$ ed., Academic Press, Oxford, 1-16.

Dittmann, K., Grupe, G., Manhart, H., Peters, J., Strott, N. 2006, Histomorphometry of mammalian and avian compact bone, in: Microscopic examinations of bioarchaeological remains:keeping a close eye on ancient tissues, Grupe G., Peters J. (eds.), Verlag Marie Leidorf, Leidorf, 48-101.

Eidlin, L. M. 1974, O wosmoschnosti opredelenia po mikrostrukture kostei wodowei prinadleschnosti i wosrasta, Sudebno-meditsinskaya ekspertiza, Vol. 17, 3-8.

Ericksen, M., Stix, A. 1991, Histologic examination of age of the first African Baptist church adults, American Journal of Physical Anthropology, Vol. 85(3), 247-252. https://doi.org/10.1002/ajpa.1330850302

Frost, H. 1987, Secondary osteon populations:an algorithm for determining mean bone tissue age, American Journal of Physical Anthropology, Vol. 30(58), 221-238. https://doi.org/10.1002/ajpa.1330300512

Gonçalves, D., Thompson, T. J. U., Cunha, E. 2011, Implications of heatinduced changes in bone on the interpretation of funerary behaviour and practice, Journal of Archaeological Science, Vol. 38(6), 1308-1313. https://doi.org/10.1016/j.jas.2011.01.006

Gregl, Z. 1997, Rimske nekropole sjeverne Hrvatske/The Roman Cemeteries of Northern Croatia, Arheološki muzej Zagreb, Zagreb.

Han, S. H., Kim, S. H., Ahn, Y. W., Huh, G. Y., Kwak, D. S., Park, D. K., Lee, U. Y., Kim, Y. S. 2009, Microscopic age estimation from the anterior cortex of the femur in Korean adults, Journal of Forensic Sciences, Vol. 54(3), 519-522. https://doi.org/10.1111/j.1556-4029.2009.01003.x

Hillier, M. L., Bell, L. S. 2007, Differentiating Human Bone from Animal Bone: A Review of Histological Methods, Journal of Forensic Sciences, Vol. 52(2), 249-263. https://doi.org/10.1111/j.15564029.2006.00368.x

Hincak, Z., Mihelić, D., Bugar, A. 2007, Cremated Human and Animal Remains of the Roman Period - Microscopic Method of Analysis (Šepkovčica, Croatia), Collegium Antropologicum, Vol. 31(4), 11271134.

Kenyeres, B., Hegyi, M. 1903, Unterscheidung des menschlichen u. tierischen Knochengewebes, Vierteljahrsschrift für gerichtliche Medizin,
Vol. 25, 225-232.

Kerley, E., Ubelaker, D. 1978, Revisions in the microscopic method of estimating age at death in human cortical bone, American Journal of Physical Anthropolology, Vol. 49(4), 545-546. https://doi. org/10.1002/ajpa.1330490414

Kerley, E. R. 1965, The microscopic determination of age in human bone, American Journal of Physical Anthropolology, Vol. 23(2), 149-163. https://doi.org/10.1002/ajpa.1330230215

Kleppinger, L. L. 2006, Fundamentals of Forensic Anthropology, John Willey \& Sons, Hoboken, New Jersey.

Lochte, T. 1914, Gerichtsarztliche und polizeiarztliche Technik. Eine Handbuch für Studierende, Ärzte, Medizinalbeamte und Juristen, J. F. Bergmann, Wiesbaden.

Lynnerup, N., Frohlich, B., Thomsen, J. 2006, Assessment of age at death by microscopy: unbiased quantification of secondary osteons in femoral cross sections, Forensic Science International, Vol. 159 (Supplement), S100-S103. https://doi.org/10.1016/j.forsciint.2006.02.023

Mann, R. W., Hunt, D. R. 2005, Photographic Regional Atlas of Bone Disease: A Guide to Pathologic and Normal Variation in the Human Skeleton, Charles C. Thomas, Springfield.

May, S. E. 2011, The effects of body mass on cremation weight, Journal of Forensic Sciences, Vol. 56, 3-9.

Munsell, 2000, Munsell Soil Colour Charts, Gretag Macbeth, New Windsor (NY).

Noy, D. 2000, Building a Roman Funeral Pyre, Antichthon, Vol. 34, 30-45. https://doi.org/10.1017/S0066477400001167

Parry, J. P. 1994, Death in Banaras, Cambridge University Press, Cambridge.

Pfeiffer, S. 1980, Bone-remodelling age estimates compared with estimates by other techniques, Current Anthropology, Vol. 21, 793794. https://doi.org/10.1086/202571

Ponsold, A. 1967, Lehrbuch der Gerichtlichen Medizin für Mediziner und Juristen, 3. Aufl., Thieme, Stuttgart.

Rambachan, A. 2003, The Hindu Way of Death, in: Handbook of Death and Dying, Bryant C. D. (ed.), Sage Publications, Thousand Oaks (CA), 640-648.

Robling, A., Stout, S. 2000, Methods of determining age at death using bone microstructure, in: Biological anthropology of the human skeleton, $1^{\text {st }}$ ed., Katzenberg M. A., Saunders S. R. (eds.), Wiley-Liss, New York, 187-214.

Robling, A, Stout, S. 2008, Histomorphometry of human cortical bone: applications to age estimation, in: Biological anthropology of the human skeleton, $2^{\text {nd }}$ ed., Katzenberg M. A, Saunders S. R. (eds), John Wiley Sons, New Jersey, 149-171.

Snoeck, C., Schulting, R. J., Lee-Thorp, J. A., Lebon, M., Zazzo, A. 2016, Impact of heating conditions on the carbon and oxygen isotope composition of calcined bone, Journal of Archaeological Science, Vol. 65, 32-43. https://doi.org/10.1016/j.jas.2015.10.013

Stout, S. D., Gehlert, S. J. 1982, Effects of field size when using Kerley's histological method for determination of age at death, American Journal of Physical Anthropology, Vol. 58, 123-125.

Stout, S. D., Stanley, S. C. 1991, Percent osteonal bone versus osteon counts: The variable of choice for estimating age at death, American Journal of Physical Anthropolology, Vol. 86(4), 515-519. https://doi. org/10.1002/ajpa.1330860407

Stout, S. D., Paine, R. R. 1992, Histological age estimation using rib and clavicle, American Journal of Physical Anthropolology, Vol. 87(1), 111-115. https://doi.org/10.1002/ajpa.1330870110

Streeter, M. 2010, A four-stage method of age at death estimation for use in the subadult rib cortex, Journal of Forensic Scence, Vol. 55(4), 1019-1024. https://doi.org/10.1111/j.1556-4029.2010.01396.x

Streeter, M. 2012, Histological age-at-death estimation, in: Bone Histology. An Anthropological Perspective, Crowder C., Stout S. (eds.), CRC Press, Boca Raton,135-152.

Symes, S. A., Rainwater, C. W., Chapman, E. N., Gipson, D. R., Piper, A. L. 2015, Patterned thermal destruction in a forensic setting, in: The analysis of burned human remains, Schmidt, C. W., Symes S. A. (eds.), $2^{\text {nd }}$ ed., Academic Press, Oxford, 17-60.

Thompson, T. J. U. 2004, Recent advances in the study of burned bone and their implications for forensic anthropology, Forensic Scien- 
ce International, Vol. 146 (Supplement), S203-S205. https://doi. org/10.1016/j.forsciint.2004.09.063

Thompson, T. J. U., Islam, M., Bonniere, M. 2013, A new statistical approach for determining the crystallinity of heat-altered bone mineral from FTIR Spectra, Journal of Archaeological Science, Vol. 40(1), 416-422. https://doi.org/10.1016/j.jas.2012.07.008

Thompson, T. J. U., Szigeti, J., Gowland, R. L., Witcher, R. E. 2016, Death on the frontier: Military cremation practices in the north of Roman Britain, Journal of Archaeological Science, Vol. 10, 828-836. https:// doi.org/10.1016/j.jasrep.2016.05.020

Trotter, M., Hixon, B. B. 1973, Sequential changes in weight, density, and percentage of ash weight of human skeletons from an early fetal period through old age, The Anatomical Record, Vol. 179(1), 1-18. https://doi.org/10.1002/ar.1091790102

Ubelaker, D. H. 2009, The forensic evaluation of burned skeletal remains: A synthesis, Forensic Science International, Vol. 183(1-3), 1-5. https://doi.org/10.1016/j.forsciint.2008.09.019
Villa, C., Lynnerup, N. 2010, Technical note: A stereological analysis of the cross-sectional variability of the femoral osteon population, American Journal of Physical Anthropolology, Vol. 142(3), 491-496. https://doi.org/10.1002/ajpa.21269

Walcher, K. 1950, Leitfaden der gerichtlichen Medizin, Urban und Schwarzenberg, München, Berlin.

Walker, P. L., Miller, K. W. P., Richman, R. 2008, Time, temperature, and oxygen availability: an experimental study of the effects of environmental conditions on the color and organic content of cremated bone, in: The Analysis of Burned Human Remains, Schmidt, C. W., Symes S. A. (eds.), Academic Press, London, 129-135.

Warren, M. W., Maples, W. R. 1997, The anthropometry of contemporary commercial cremation, Journal of Forensic Sciences, Vol. 42(3), 417-423.

Wieweigh, Z. 2003, Jugoistočna nekropola Siscije, Gradski muzej Sisak, Sisak.

\section{IZVOR / SOURCE}

Vitruvije, M. P. 1999, De Architectura Libri Decem, Golden marketing, Tehnička knjiga, Zagreb. 